\title{
Investigating Financial Statement Fraud in Ghana Using Beneish M-Score: A Case of Listed Companies on the Ghana Stock Exchange
}

\author{
Mike Adu-Gyamfi \\ Swiss Management Center University \\ Bahnhofstrasse 20, 6300 Zug, Switzerland \\ E-mail:m_adugyamfi@yahoo.com
}

Received: June 26, 2020

Accepted: August 8, $2020 \quad$ Published: September 18, 2020

doi:10.5296/ifb.v7i2.17710

URL: http://dx.doi.org/10.5296/ifb.v7i2.17710

\begin{abstract}
This quantitative research was conducted to detect the possibility of earnings manipulation by listed companies on the Ghana Stock Exchange, determine the relationship between company size and earnings manipulation and find out the existence of a correlation between share price and earnings manipulation. Using 22 companies out of a total of 41 listed companies, financial data gathered from published financial statements on the companies' websites, Ghana Stock Exchange website and Annual Report Ghana website were examined from 2011 to 2016. Applying Beneish M-score model for the period 2011-2016, it was found that $26.2 \%$ of the sample size on the average were involved in creative accounting. The study also found that $28.4 \%$ of the small companies on the average were involved in earnings manipulation during the period 2011-2016 as compared to $25.4 \%$ of the big companies. However, the Mann-Whitney $U$ test conducted revealed that there is no statistically significant difference between the level of earnings manipulation and company size. Spearman's correlation analysis was conducted, firstly, on the entire sample and separately on the small and big companies. The results of the analysis showed that earnings manipulation and share price, statistically, were not significantly correlated. The quantitative research provides an insight into the level of earnings management amongst listed companies in Ghana and the appropriateness of the $\mathrm{M}$-score model in detecting earnings manipulation. The evidence of incidence of creative accounting amongst the sampled companies is an indication of the need for more stringent measures to curb such practice to ensure the stability of the Ghanaian stock market and protect investor interest.
\end{abstract}

Keywords: Earnings manipulation, Beneish M-score model, Spearman Correlation Analysis, Ghana Stock Exchange, Mann-Whitney U test 


\section{Introduction}

\subsection{Overview}

This quantitative research involves the study of earnings manipulation amongst listed companies on the Ghana Stock Exchange (GSE). It explores whether the non-banking and finance companies listed on the GSE engaged in creative accounting between 2011 and 2016. It also explores the relationship between earning manipulation and company size as well as the association between earnings manipulation and share price. This research applied quantitative research methodology to determine the possibility of earnings manipulation amongst the sampled listed companies in Ghana and the level of creative accounting by company size using Beneish's M-Score model and Mann-Whitney U Test (Beneish, 1999; Repousis, 2016; Weaver, Morales, Dunn, Godde, \& Weaver, 2018). Additionally, this dissertation used Spearman Correlation Analysis to investigate the correlation between earnings manipulation and share price and test the statistical significance between the two variables for the entire sample size and by company size. Annual financial reports of the listed companies from the Ghana Stock Exchange, Annual Reports Ghana and the companies' websites were used for this research. This research is intended to help investors to make better investment decisions and provide an indication of the stability of the Ghana Stock Exchange.

\subsection{Problem Statement}

Beneish (1999) refers to earnings manipulation as a situation where a company's management breaches the Generally Accepted Accounting Principles (GAAP) in order to present favorable financial performance for the company by either deflating expenses or inflating revenues. The issue of earnings manipulation is of great concern to many across the world. This stems from the devastating effects of earnings manipulation when it occurs (Filip \& Raffournier, 2014; Ge \& Kim, 2014). Earnings manipulation perpetrated by companies, particularly large conglomerates such as Lehman Brothers, Enron and WorldCom in the United States, led to loss of billions of United States dollars. Lehman Brothers, for instance, enhanced its balance sheet by US\$50 billion using repurchase agreements (Sharp, 2010 as cited in Adu-Gyamfi, 2016). Ghana has not been spared of this ugly side of financial accounting manipulation. In the 1990s, many investors were defrauded by activities of Pyram and Resource 5 (R5) which were micro-finance companies (Konrad Adenauer Foundation, 2006). The Bank of Ghana suspended the operations of some micro-finance companies in 2015 including Diamond Micro-Finance Limited (DKM) for various manipulations and breaches which resulted in their inability to pay investors' funds. The micro included (Boateng, 2015 as cited in Owusu \& Amo, 2016). Between August 2017 and August 2018, seven banks namely UT Bank Limited, Capital Bank Ghana Limited, Unibank Ghana Limited, The Royal Bank Limited, Sovereign Bank Limited, Beige Bank Limited and Construction Bank Limited collapsed in Ghana (Bank of Ghana [BOG], 2018; BOG, 2017). GCB Bank Limited took over the assets and liabilities of UT Bank Limited, which was formerly listed on the Ghana Stock Exchange, and Capital Bank Ghana Limited in August 2017 (BOG, 2017). The Central Bank of Ghana revoked the licenses of the remaining five 
insolvent banks above and consolidated them into Consolidated Bank Ghana Limited. Most of these banks were reported to have engaged in some accounting manipulations. According to BOG (2018), Sovereign Bank Limited and The Beige Bank Limited "obtained their banking licenses under false pretenses through the use of suspicious and non-existent capital which has resulted in a situation where their reported capital is inaccessible to them for their operations" (p. 2). Unibank Ghana Limited was reported to have granted loans amounting to GHC3.7 billion to shareholders and related parties without due process and failed to recognize such loans as part of its loan portfolio. The Bank also underestimated its total customer deposits by GHC2.3 billion and overstated its loans and advances to customers by GHC1.3 billion (BOG, 2018). The Bank of Ghana further reported that The Royal Bank Limited circumvented single obligor limits and overstated its capital with the aim of meeting the capital adequacy limits (BOG, 2018). Regarding Sovereign Bank Limited, an amount of GHC80 million reported by the bank to be part of its paid-up capital and supposedly placed with other banks were inaccessible (BOG, 2018). What makes it more worrying was effects of these happenings on the Ghana Stock Exchange and investors since one of these banks UT Bank Limited - was listed on the Exchange. Accounting fraud has the potential of deceiving investors into taking unfavorable investment decision, creating loss of confidence and distortions in the affected companies as well as the financial system in general, and ultimately plummeting of their share values. (Beneish, 1999; Sharp, 2010 as cited in Adu-Gyamfi, 2016). The major concern is that little has been done to investigate possible manipulations prior to the collapse of companies and institute the necessary actions to curb their impact and prevent future occurrence (Amoa-Gyarteng, 2014). Amoa-Gyarteng (2014) conducted a study on only AngloGold Ashanti, a gold mining company listed on the GSE, for bankruptcy signal and accounting manipulations between 2010 and 2012. It was found that the organization was not involved in earnings manipulation over the period examined but showed signs of financial distress during all the years examined. A wider approach involving investigation of a larger sample size on the GSE for possible earnings manipulation was, therefore, eminent.

\subsection{Research Questions and Hypotheses}

The dissertation' objectives were as follows:

1) Determine the possibility of earnings manipulation by non-banking and finance companies listed on the Ghana Stock Exchange using the M-Score model from 2011 to 2016;

2) Determine whether small companies engage more in creative accounting relative big companies or vice versa;

3) Investigate the relationship between earnings manipulation and share price.

Based on the above objectives, this dissertation intended to answer the following questions:

R1: Are companies listed on the Ghana Stock Exchange manipulating their earnings?

R2: Do small companies listed on Ghana Stock Exchange manipulate their earnings more than big companies? 
R3: Is there a relationship between share price and M-score?

Based on the research questions, the researcher tested the following three (3) sets of hypotheses:

$\mathrm{H}_{01}$ : No listed companies in Ghana engage in earnings manipulation.

$\mathrm{H}_{\mathrm{A} 1}$ : Some listed companies in Ghana engage in earnings manipulation.

$\mathrm{H}_{02}$ : Small companies listed on the Ghana Stock Exchange do not manipulate their earnings more than big companies listed on the Ghana Stock Exchange.

$\mathrm{H}_{\mathrm{A} 2}$ : Small companies listed on the Ghana Stock Exchange manipulate their earnings more than big companies listed on the Ghana Stock Exchange.

$\mathrm{H}_{03}$ : Share price is not related to M-Score.

$\mathrm{H}_{\mathrm{A} 3}$ : Share price is related to M-Score.

\subsection{Assumptions and Limitations}

All data gathered for this quantitative research were from the annual financial statements of the sampled companies' websites, Ghana Stock Exchange website and Annual Reports Ghana website. This research applied the assumption that the sampled companies were listed on the stock exchange. The limitations of this study were as follows:

- The financial data used were from 2011 to 2016;

- Not all the listed companies on the Ghana Stock Exchange were used in this research. Only 22 non-banking and financial companies were used for the research;

- Some firms had no data available for the years 2014 to 2016. The primary reason being that they had not published their financial statements;

- Only secondary data were used for the dissertation. This was because the methodology applied only required secondary data.

\subsection{Organization of the Research}

This research is organized into five sections. The research begins with an introduction, followed by the literation review section. The third and fourth sections cover the methodology and data and empirical results respectively. The final section presents a summary of the research and recommendations.

\section{Literation Review}

\subsection{Introduction}

This section primarily covers the theoretical orientation, existing literature and synthesis of the research. The first part of this section details the theoretical orientation of the research and involves a discussion on the background of the Ghana Stock exchange including the history, milestones achieved since inception as well as its performance over the period amongst other 
things. The next two parts of this section deal with existing literature and synthesis of the research respectively. Essentially, they present a detailed review of the earnings manipulation theories, theories on the association of company size and earnings manipulation and theories on association of earnings manipulation and share price. (Beneish, 1999; Burgstahler \& Dichev, 1997 as cited in Kighir; Eldenburg, Gunny Omar, \& Mohammed, 2014; Hee \& Soderstrom, 2011; Mahama, 2015). The subsection on synthesis of this quantitative research identifies and discusses some studies that had been conducted within a two-decade period from 1997 to 2017 (Beneish, 1997, 1999; Kighir et al., 2014; McLeavey, 2013; Namazi \& Maharluie, 2015; Nwoye et al., 2012; Repousis, 2016; Tarjo \& Herawati, 2015). This subsection also involves the findings and conclusions of several studies on the M-Score model and other methods used for detecting earnings manipulation (Beneish, 1997, 1999; Kighir et al., 2014; McLeavey, 2013; Namazi \& Maharluie, 2015; Nwoye et al., 2012; Repousis, 2016; Tarjo \& Herawati, 2015).

\subsection{Theoretical Orientation}

The establishment of the Ghana Stock Exchange dates back to 1989 when Ghana collaborated with the Bretton Woods' institutions and other development partners to undertake a comprehensive structural adjustment program referred to as Financial Services Adjustment Program, FINSAP 1 \& 2 (Acquah, 2016; Acquah-Sam, 2014). Prior to this, the Stock Exchange Act of 1971 had been enacted to provide the legal framework for the establishment of Accra Stock Market Limited (ASML) in 1971 but it could not materialize in the mist of unstable political and unfavorable macroeconomic environment amongst others (Adam, 2011; Ziorklui, 2001). Only shares of selected companies owned by foreigners were traded over-the-counter (Ziorklui, 2001). The Ghana Stock Exchange's legal status changed from a private firm to a public firm in 1994.

According to the Ghana Stock Exchange [GSE] (2017), the GSE was established to provide the requisite facilities and framework to enable the trading of securities, regulate the granting of quotations on the capital market, organize stock dealings and facilitate the exchange of information, collaborate with stakeholders in other countries and make available to market participants information that may be useful to them, and to ensure that the dealings amongst markets participants are regulated.

The GSE was recognized by law in Ghana and began trading on 12th November 1990 (Adam, 2009). Commencing operations with only 3 brokerage firms and 11 listed companies in November 1990, the Ghana Stock Exchange has grown to become a major platform for capital raising and investment (Ziorklui, 2001). The number of listed companies increased to 13 in 1991, 19 in 1995, 32 in 2007 and 39 in 2015 (GSE, 2007a as cited in Adam \& Tweneboah, 2009; GSE, 2015). 
Table 1. Landmarks of Ghana Stock Exchange (GSE, 2017)

\begin{tabular}{|c|c|}
\hline Period & Landmark \\
\hline 1969 & $\begin{array}{l}\text { The Pearl Report by Commonwealth Development Finance Co. recommended the establishment } \\
\text { of a stock exchange in Ghana within two years and suggested ways of achieving it. Various } \\
\text { committees established by different governments to explore ways of bringing into being a } \\
\text { Stock Exchange in the country. }\end{array}$ \\
\hline 1971 & The Stock Exchange Act was enacted. \\
\hline 1971 & The Accra Stock Exchange Company was incorporated but never operated \\
\hline Feb-1989 & $\begin{array}{l}\text { Provisional National Defense Council (PNDC) government set up a 10-member National } \\
\text { Committee on the establishment of the Stock Exchange under the chairmanship of Dr. G.K. } \\
\text { Agama, the then Governor of the Bank of Ghana. }\end{array}$ \\
\hline July-1989 & $\begin{array}{l}\text { Ghana Stock Exchange was incorporated as a private company limited by guarantee under } \\
\text { the Companies Code } 1963 .\end{array}$ \\
\hline Oct-1990 & $\begin{array}{l}\text { Executive Instrument No. } 20 \text { giving recognition to Ghana Stock Exchange as an authorized } \\
\text { Stock Exchange signed. }\end{array}$ \\
\hline Nov-1990 & $\begin{array}{l}\text { Council of the Exchange adopted operational regulations namely, GSE Membership } \\
\text { Regulations L.I. 1510, Listing Regulations L.I } 1509 \text { and Trading and Settlement Regulations. }\end{array}$ \\
\hline Nov-1990 & First Council of the Exchange with Mrs. Gloria Nikoi as Chairperson was inaugurated. \\
\hline Nov-1990 & Trading commenced on the floor of the Exchange \\
\hline Jan-1991 & Ghana Stock Exchange was officially launched \\
\hline Sept-1993 & The Exchange moved to its present offices, 5th Floor, Cedi House, Liberia Road, Accra \\
\hline April-1994 & $\begin{array}{l}\text { A resolution passed at the AGM changed the Exchange from a private company limited by } \\
\text { guarantee to that of a public company limited by guarantee under the Company Code } 1963 \\
\text { (Act 179) }\end{array}$ \\
\hline
\end{tabular}

Table 1 shows landmarks achieved by the Ghana Stock Exchange over the years.

Since January 2011, two market indices have been published by the GSE. These market indices are the GSE Composite Index (GSE-CI) and the GSE Financial Stocks Index (GSE-FSI) (GSE, 2017; IC Securities, 2011). The GSE-CI's computation is based on the volume weighted average closing price of the entire shares listed on the Ghana Stock Exchange using the base date of December 31, 2010 and the base index value of 1000 (GSE, 2017; IC Securities, 2011). Using the same base date and base index value, GSE Financial Stocks Index (GSE-FSI) constitutes listed equities in the financial sector including banking and insurance industry equities (GSE, 2017).

The Ghana Stock Exchange recorded an enviable performance in the past. The stock market of Ghana was adjudged the best performing emerging market in 1994 with return of $124.3 \%$ (Angko, 2013; GSE, 1995 as cited in Adam \& Tweneboah, 2009). The Ghanaian stock market also recorded the highest return of 144\% in the world in 2004 (Databank Group, 2004 as cited in Acquah-Sam, 2016). 


\section{Macrothink}

Table 2. GSE Composite Index Summary November-December 1990-December 2015 (GSE, 2015)

\begin{tabular}{lllllll}
\hline Period & High & Date & Low & Date & End of Period Index & Percentage Change \\
\hline $\begin{array}{l}\text { Nov - Dec } \\
1990\end{array}$ & 77.65 & 12-Nov & 70.08 & 21-Dec & 70.08 & 0.00 \\
1991 & & & & & & \\
1992 & 69.77 & 4-Jan & 55.49 & 17-May & 64.51 & $(7.95)$ \\
1993 & 12.90 & 6-Oct & 60.15 & 23-Jun & 62.17 & $(3.63)$ \\
1994 & 332.88 & 30-Dec & 63.29 & 5-Jan & 132.88 & 113.74 \\
1995 & 322.11 & 17-May & 132.91 & 4-Jan & 298.10 & 124.34 \\
1996 & 385.80 & 13-Oct & 296.32 & 22-Mar & 316.97 & 6.33 \\
1997 & 524.21 & 8-Dec & 307.42 & 12-Jan & 360.76 & 13.82 \\
1998 & $1,201.08$ & 6-May & 511.66 & 31-Jan & 511.74 & 41.85 \\
1999 & 903.17 & 5-Feb & 735.39 & 22-Dec & 736.16 & 69.69 \\
2000 & 873.35 & 22-Sep & 737.16 & 3-Jan & 857.98 & $(15.22)$ \\
2001 & $1,025.78$ & 1-Aug & 856.00 & 7-Feb & 955.95 & 16.55 \\
2002 & $1,395.31$ & 30-Dec & 955.95 & 2-Jan & $1,395.31$ & 11.42 \\
2003 & $3,553.42$ & 31-Dec & $1,395.36$ & 2-Jan & $3,553.42$ & 45.96 \\
2004 & $7,469.04$ & 25-Aug & $3,558.96$ & 2-Jan & $6,798.59$ & 154.67 \\
2005 & $6,901.36$ & 28-Jan & $4,751.17$ & 22-Dec & $4,769.02$ & $(29.85)$ \\
2006 & $5,006.02$ & 29-Dec & $4,692.84$ & 31-Jan & $5,006.02$ & 4.97 \\
2007 & $6,599.77$ & 31-Dec & $5,001.15$ & 11-Jan & $6,599.77$ & 31.84 \\
2008 & $10,931.36$ & 3-Oct & $6,595.92$ & 2-Jan & $10,431.64$ & 58.06 \\
2009 & $10,431.64$ & 2-Jan & $5,098.92$ & 17-Aug & $5,572.34$ & $(46.58)$ \\
2010 & $7,185.05$ & 1-Jun & $5,463.83$ & 14-Jan & $6,886.31$ & 32.25 \\
2011 & $1,189.77$ & 18-May & 940.04 & 16-Dec & 969.03 & $(3.10)$ \\
2012 & $1,199.72$ & 31-Dec & 968.08 & 5-Jan & $1,199.72$ & 23.81 \\
2013 & $2,341.60$ & 2-Dec & $1,198.29$ & 3-Jan & $2,255.52$ & 78.81 \\
2014 & $2,439.20$ & 21-Feb & $2,145.20$ & 2-Jan & $2,261.02$ & 5.40 \\
2015 & $2,386.51$ & 9-Jun & $1,954.21$ & 11-Dec & $1,994.91$ & $(11.77)$ \\
\hline & & & & & &
\end{tabular}

Besides, the GSE - Composite Index (GSE-CI) recorded 78.81\% in 2013 as shown in Table 2, placing the GSE amongst the best performing Sub-Saharan African stock exchanges (Acquah-Sam, 2016; GSE, 2015). In addition, market capitalization witnessed a remarkable appreciation increasing from US\$2.6 million in 1995 to US\$15 billion in 2015 (GSE, 2015; GSE, 1995 as cited in Adam \& Tweneboah, 2009). 


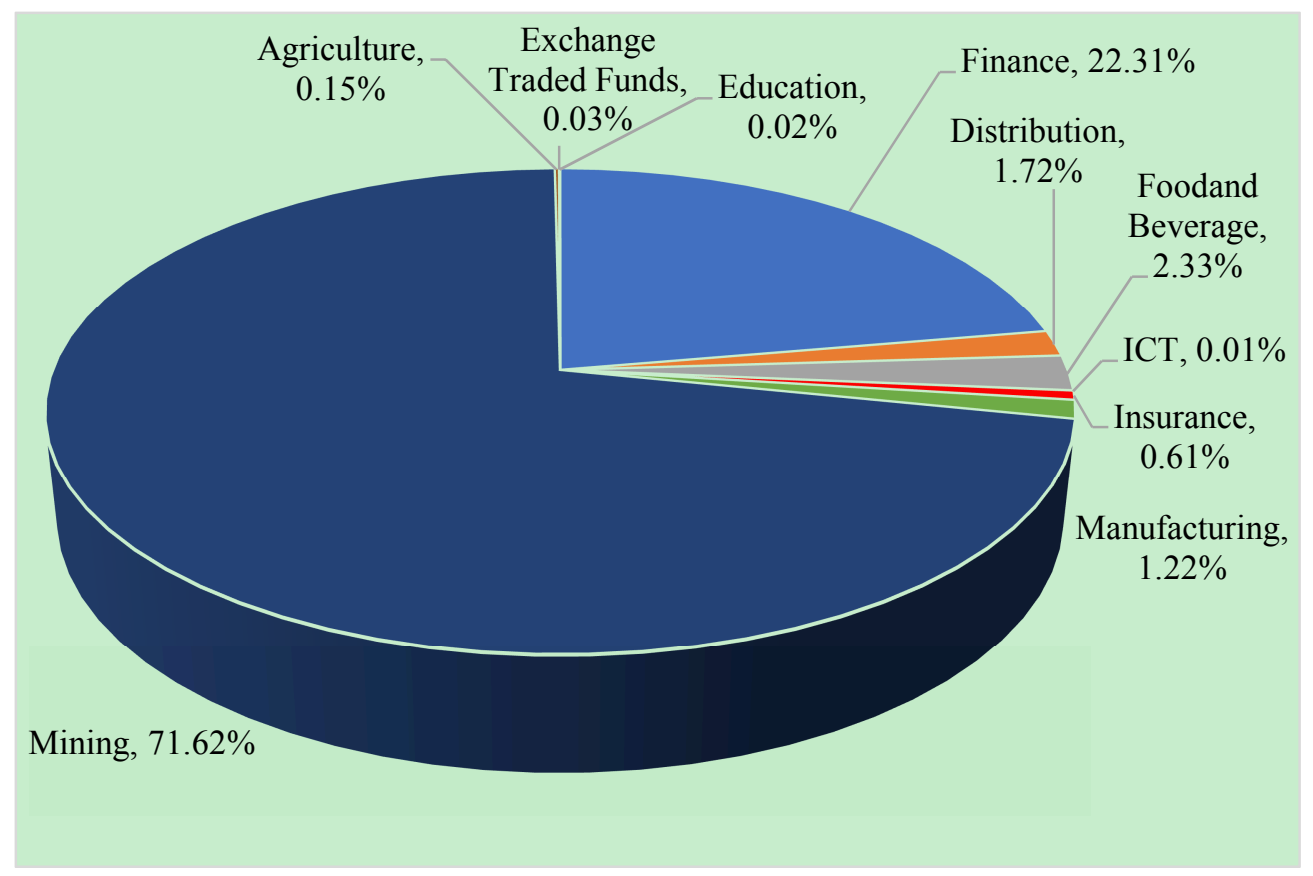

Figure 1. GSE Market Capitalization per Sector as at December 2015 (BOG, 2016)

In terms of industry contribution to market capitalization, the mining sector dominated the Ghana Stock Exchange as at December 2015, accounting for approximately $71.6 \%$, followed by Finance Sector with $22.3 \%$ as depicted in Figure 1 (GSE, 2015). The Ghana Stock Exchange has become a very important source for raising long-term capital for public and private developmental projects. According to Angko (2013), most economists recognize the importance of a well-organized stock market as a critical ingredient for successful mobilization of both domestic and foreign capital. It was estimated that GHC2.2 billion (US\$557.8 million) equity and corporate actions primary issues were undertaken in 2015, whilst government and corporate bonds issued stood at 160 million cedi-denominated and 2 billion dollar-denominated (GSE, 2015). 


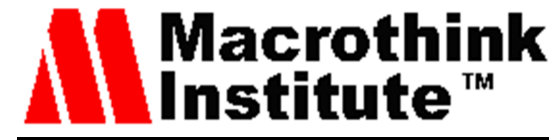

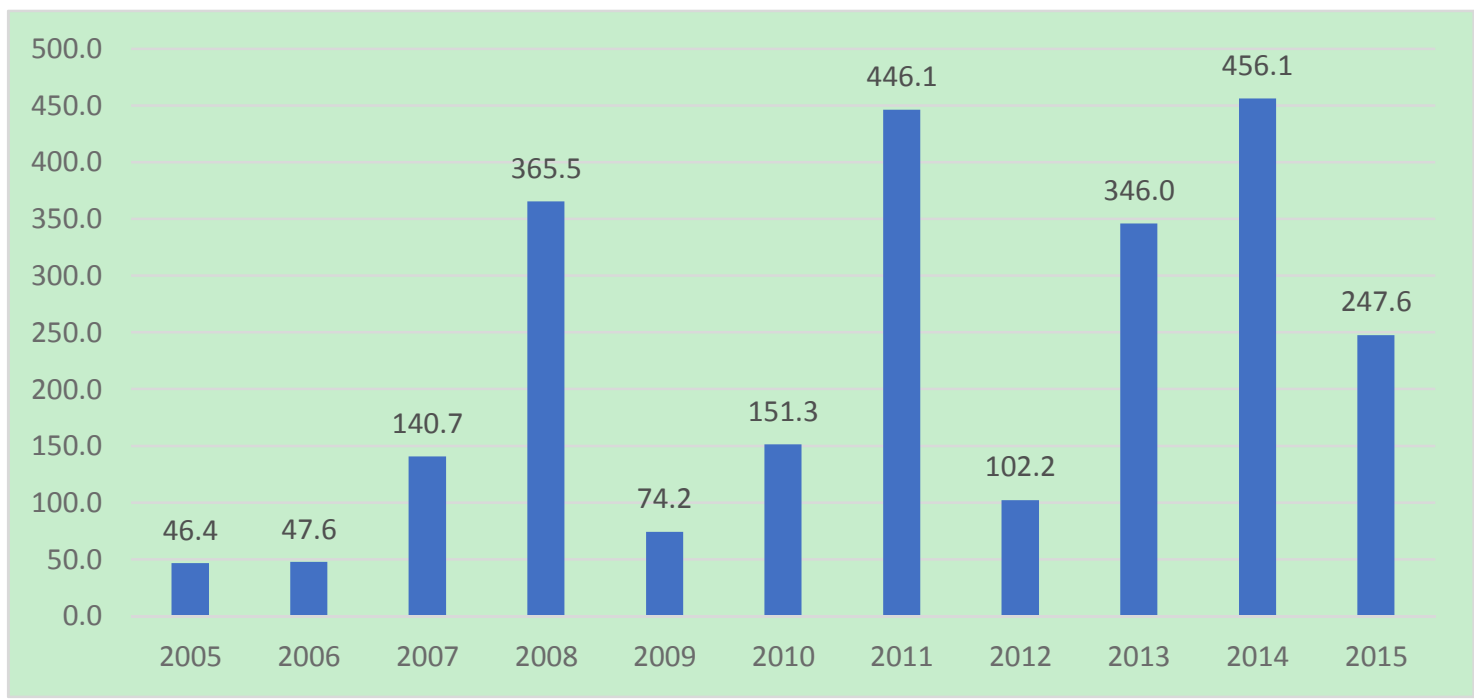

Figure 2. Volume Traded on the GSE in Millions of Cedis from 2005-2015 (GSE, 2014; GSE, 2015; GSE, 2016a)

The volume traded on the GSE showed an intermittent trend between 2005 and 2015, recording the highest amount of GHC456.1 million in 2014 and lowest amount of GHC46.4 million in 2005 as shown in Figure 2 (Ghana Stock Exchange [GSE], 2016a; GSE, 2015; Ghana Stock Exchange [GSE], 2014). Figure 2 also shows that the volume traded increased consistently between 2005 and 2008 and fell in 2009. The poor performance of the stock market in 2009 was attributed to factors including the global financial crisis, sluggish economic growth of the Ghanaian economy and a shift in investor preference from stocks to relatively higher yielding short term securities (BOG, 2009). The activities in the stock market assumed an increasing trend until 2015 when it experienced a sharp decline as shown in Figure 2 (GSE, 2016a; GSE, 2015; GSE, 2014). The slowdown of the activities on the stock market was attributed to shift in investor preference for higher yielding short term instruments, weak macroeconomic fundamentals, a decrease in stock prices particularly during first two quarters of the year amongst others (BOG, 2015).

The aforementioned analysis demonstrates the important intermediation role of stock markets, ensuring that resources are transferred from surplus units to deficit units. According to Angko (2013), the performance of a stock market contributes immensely to the development agenda of every economy. Angko (2013)'s assessment is based on the positive effects that stock markets have on funding of businesses as well as economic activities in general. Hence, stock exchanges are expected to serve as a catalyst for economic growth by improving financial assets liquidity, promoting easier risk diversification and informed investment decision. Anyamele (2013) found that private capital stock market development, foreign direct investment, stock market capitalization, money supply and stock turnover ratio are positively related to growth in per capita GDP in Sub-Sahara Africa. Stock exchange facilitates economic growth (Ghana Stock Exchange [GSE], 2016b).

In spite of various achievements of the Ghana Stock Exchange including increase in listed 
equities from 11 at inception to about 41, increase in number of License Dealing Members from 3 at inception to 21 , over 90 government bonds issued, a fully automated trading system as opposed to the manual system at inception, the introduction of Alternative Market (GAX) for small and medium scale enterprise (SMEs) and over GHC2 billion worth of equity raised through the Exchange, it is still saddled with numerous challenges (Adusei, 2014; GSE, 2016b; Mensah, Awunyo-Vitor, \& Sey, 2012; Owusu \& Odhiambo, 2013). Notably amongst these challenges are low liquidity, limited number of listings, limited number of instruments and limited investor participation (GSE, 2016b). Other authors have also cited challenges such as lack of education on the Exchange, outmoded method of doing business, lack of efficiency, return volatility, non-performing firms, exorbitant listing cost, non-existence of credit rating agencies, inadequate capitalization of Licensed Dealing Members, as well as existence of rigid regulations (Mensah et al., 2012; Owusu \& Odhiambo, 2013). Unavailability of more liquid financial securities, demand and supply influence investment decisions and securities prices instead of the firms' actual performances (Ayentimi, Mensah, \& Naa-Idar, 2013). The lack of adequate liquidity is worrying due to its negative impact on capital market development. Boachie, Mensah, Frimpong and Ruzima (2016) identified liquidity growth and inflation to be directly related to the performance of the Ghana Stock Exchange and exchange rate to be inversely related the performance of the Ghana Stock Exchange. Based on empirical analysis, Ayentimi et al. (2013) also found Ghana Stock Market to be inefficient. The Stock Market is also bedeviled by lack of education. The need to intensity education on the stock market activities to attract more investors is very critical to the growth of the Exchange (Ofori-Abebrese, Amporfu, \& Adu, 2016).

The Government of Ghana over the years has initiated various measures towards making activities of the GSE more attractive and strengthening the capacity of the Exchange. In addition to the provision of the requisite legal framework for its establishment, the Government of Ghana put in place certain tax incentives such as tax exemption for capital gains from listed companies, a 3\% tax reduction within the first three years of becoming a public company and tax exemption for the Ghana Stock Exchange amongst others (GSE, 2016b). Investor protection has also been identified as a key ingredient for a stable and well patronaged stock exchange and investor confidence. In this regard, there are specific provisions in the GSE's rules designed to ensure that investors are protected including access to credible information. In addition, the Securities Industry Law, PNDCL 333 (1993), as amended, empowers the SEC to:

- $\quad$ oversees the securities industry with the aim of ensuring a well-organized and impartial dealing in securities (GSE, 2017);

- $\quad$ register, license and authorize stakeholders in the securities industry including the stock exchange, securities dealers and investment advisors (GSE, 2017);

- guard against any abuse from insider trading with the view of ensuring that the securities market's integrity is protected (GSE, 2017).

It is an offence under the Securities Industry Law 1993 if: 
- $\quad$ a person creates false or misleading impression to deceive others into believing that a financial instrument is in active trading on the GSE (GSE, 2017);

- a person is involved in two or more transactions that have the potential of leading to increasing or decreasing in the securities prices to induce other persons to trade in the securities (GSE, 2017);

- a person makes a false or misleading statement to persuade others to trade in financial instruments (GSE, 2017);

- $\quad$ a person makes a false or misleading statement to the SEC Commission or GSE, in respect of dealing in securities with an intention to create deception (GSE, 2017);

- $\quad$ if a person, with an intention to induce others to trade in financial assets, he/she uses scheme or engage in deceitful act (GSE, 2017);

- A broker-dealer refuses to maintain proper accounting records including explanations of its financial position and all transactions (GSE, 2017).

The penalty for these offenses includes monetary fines and imprisonment (GSE, 2017)

The soundness and stability of the GSE should be of critical concern to all well-meaning people (Aryeetey \& Kanbur, 2017). Investor confidence, professional and credible reporting, liquidity, education amongst others constitute hallmarks of a sound and stable stock market (Hirsch, 2012; Roze \& Roze, 2016).

\subsection{Review of Literature}

\subsubsection{Review of Earnings Manipulation Theories}

Repousis (2016) refers to financial statement fraud as a deliberate attempt to misrepresent the financial position of a company with a view to deceive others. The need to ensure quality earnings is one of the major concerns of many researchers and financial statement users. The single most important output of financial reporting is earnings (Dichev, Graham, Harvey, \& Rajgopal, 2016). Dichev et al. (2016) found that $20 \%$ of companies deliberately engage in earnings manipulation even while complying with the GAAP and estimated the magnitude of the misrepresentation to be $10 \%$ of reported earnings. Analyzing 2,410 occupational fraud cases that occurred in 114 countries, the Association of Certified Fraud Examination [ACFE] (2016) found an increasing trend in the percentage of all occupational fraud that constitute financial statement fraud. ACFE (2016) estimates financial statement fraud to represent $7.6 \%$, $9.0 \%$ and $9.6 \%$ in 2012, 2014 and 2016 respectively. In Sub-Sahara Africa, financial statement fraud represented $5.6 \%$ of all occupational fraud compared to that of Western Europe, which was $17.3 \%$ (ACFE, 2016). A large number of financial statements are manipulated in developed countries, with $55 \%$ of the cases occurring in the income account of the income statement (Mamo \& Aliaj, 2014). Mamo and Aliaj (2014) also indicated that enterprises in developed countries were characterized with very good performance prior to manipulation of their financial statements. Despite these statistics, majority of fraud are not detected since they are hidden from the public and sometimes auditors (Aghghaleh, 
Mohammed \& Rahmst, 2016). Wuerges and Borba (2010) estimated the likelihood that fraud is not detected by US Securities and Exchanges Commission to be approximately $97.61 \%$, indicating that only a small portion of fraud cases are detected by the Commission.

Financial statement fraud may be categorized into Net Income Understatement and Net Income Overstatement (ACFE, 2016). Net Income Understatement involves inflated expenses and liabilities, understated revenues, timing differences, improper disclosures and asset valuation whilst Net Income Overstatement includes hidden liabilities and expenses, improper disclosures and asset valuation, as well as timing differences (ACFE, 2016). Adkins (n.d.) outlines two general methods to financial statement manipulation. The first approach involves inflation of current period earnings by inflating incomes and gains or deflating expenses. The purpose of this approach according to Adkins (n.d.), is to portray a better picture of the actual financial condition of the company in order to meet targets. The second approach according to Adkins (n.d.), is to deflate current period earnings by deflating incomes and gains or inflate expenses with the aim of showing unfavorable financial condition of a company. The purposes for such an approach include making a company look bad so that potential investors will be deterred from acquiring it, ensuring that all the adverse financial information about a company are pulled into one period so that the company will show stronger financial position going forward, ensuring that all the adverse financial information about a company are pulled into one period when the unfavorable performance can be said to have been caused by the current macroeconomic environment, and to defer the publication of favorable financial information to a future period when such information is more likely to be recognized (Wayman, 2017).

Real earnings management is directly related to board monitoring and indirectly related to takeover protection (Ge \& Kim, 2014). The tougher board monitoring, the higher the degree of real earnings manipulation and vice versa. Similarly, higher takeover protection has the propensity to reduce managerial incentives to manage earnings (Ge \& Kim, 2014). Management may be motivated to engage in financial statement fraud or earnings manipulation in order to ensure their statuses are maintained, obtain higher stock prices, demonstrate to financiers that they are complying with certain financing covenant, meet corporate targets and investor expectation, procure funding and secure better terms for existing funding (Repouse, 2016; Adkins, n.d.). According to Mamo and Aliaj (2014) companies may report small earnings in their financial statements for tax authorities in order to pay less taxes as possible whilst other may present good financial position in order to obtain loans, avoid being processed for bankruptcy or subject of control. Companies resort to earnings smoothing due to their conviction that earnings stability has the capability of supporting higher streams of dividend than earnings variability (Kighir et al., 2014). Beneish and Nichol (2009) argued that stocks that are overvalued are characterized by "a high probability of financial statement fraud, high sales growth, low operating cash flow, and a recent history of acquisitions and stock issuance" (p. 30). Firms that have a higher chance of earnings manipulation tend to earn lower returns on every decile portfolio when it is sorted by size, book-to-market, momentum, accruals, and short interest (Beneish, Lee, \& Nichols, 2013). 
2.3.2 Review of Theories on Company Size and Earnings Manipulation Relationship

The relationship between company size and earnings management has been widely investigated and resulted in diverse opinions (Wuryani, 2012). Li (as cited in Behrahani and Pajoohi, 2016), Sayari, Mraihi, Finet and Omri (2013) and Wasilah (as cited in Wuryani, 2012) argue that there is a positive relationship between company size and earning management. This presupposes that big companies have the propensity to engage in earnings manipulations than their small counterparts. Big companies require the market's confidence, and this is possible through the provision of certain powerful information including impressive financial reports. The quest to provide such acceptable information motivates big companies to engage more in earnings manipulations (Wasilah, 2005 as cited in Wuryani, 2012).

Other researchers postulated a contrary view by providing evidence that indicate a negative relationship between company size and earnings manipulation (Alwan, 2009 as cited Wuryani, 2012; Sayari et al., 2013; Veronica \& Siddharta, 2005 as cited in Wuryani, 2012; Zhu \& Lu, 2013). Veronica and Siddharta (as cited in Wuryani, 2012) argued that there is negative and significant relationship between company size and earnings management and this is a key factor to be considered in minimizing manipulation of financial information and achieve improvement in earnings quality. Sayari et al. (2013) supported the view of negative relationship between company size and earnings manipulation and cited the dependence of government on large firms to finance national budgets through imposition of higher income taxes as reason why big comes manage their earnings downwards. Even though, Alwan (as cited Wuryani, 2012) and Hastuti and Humata (as cited in Wuryani, 2012) also supported the argument of negative relationship between company size and earnings manipulation, they found the relationship to be statistically insignificant. Zhu and $\mathrm{Lu}$ (2013) propounded that smaller bidders have higher propensity to engage in activities aimed at managing earnings in order to inflate firm value before mergers and acquisitions.

\subsubsection{Review of Theories on Earnings Manipulation and Share Price Relationship}

The relationship between earnings manipulation and share price or stock returns has also been investigated in the global research space. Beneish (1999), Nuryuman (2013) and Christianto and Budiharta (2014) suggested a negative relationship between earnings manipulation and share price or stock returns. According to Beneish (1999), firms that are detected to have engaged in earnings manipulation see their share value fall. Nuryauman (2013) is of the view that earnings management adversely impact stock returns which is as a resulted of reduced stock prices. Nuryauman (2013), therefore, supported a negative relationship between earnings manipulation and share price. Christianto and Budiharta (2014) also supported this argument by indicating that earnings manipulation as measured by M-score, negatively affect stock price and eventually stock returns. Opponents of this view include Lutfi, Nazwar, and Muda (2016) and Zhu and Lu (2013). Lutfi et al. (2016) suggested that real activity manipulation has direct impact on share price. Zhu and Lu (2013) contended that managers manipulate earnings to boost the value of their companies before mergers and acquisitions, indicating a positive relationship earnings manipulation and share value. 


\subsection{Synthesis of Research}

Earnings manipulation is a threat to a sound financial market (De la Merced \& Werdigier, 2010). The consequences of earnings manipulation can be so devastating leading to a reduction in share value, loss of confidence in the financial markets as well as financial sector instability (Beneish, 1999; Sharp, 2010 as cited in Adu-Gyamfi, 2016). The need to develop effective ways of detecting earnings manipulation and to avoid its adverse effects can therefore not be over-emphasized. In the last two decades, various attempts have been made by a number of researchers to achieve this objective (Beneish, 1997, 1999; Burgstahler \& Dichev, 1997; Eldenburg et al., 2011; Patel \& Zeckhauser, 1999; Peasnell, 2000; Penman \& Zhang, 2002; Roychowdhury, 2006). The result is the development of numerous earning manipulation detection models by various scholars (Beneish, 1999; Eldenburg et al., 2011; Peasnell, 2000; Penman \& Zhang, 2002; Roychowdhury, 2006). This section identifies some of the earnings manipulation detection models developed over the years, their applications in other parts of the world, as well as conclusions made by various researchers on detection of earnings manipulation.

Messod Daniel Beneish created a mathematical model to detect incidence of earnings manipulation and propensity to manipulate earnings using eight variables derived from financial statement data. Using a sample size of 74 companies between 1982-1992, he found that manipulators had high growth prior to the period of earning manipulation (Beneish, 1997, 1999; Repousis, 2016). With this data set, Beneish developed eight independent variables with which a mathematical score called M-Score was created (McLeavey, 2013; Nwoye et al., 2012; Repousis, 2016). The eight variables are days' sales in receivables index (DSRI), asset quality index (AQI), depreciation index (DEPI), total accruals to total assets (TATA), gross margin index (GMI), sales growth index (SGI), selling, general, and administrative expenses index (SGAI) and leverage index (LEVI) (Nwoye et al., 2013; Omar, Koya, Sanusi, \& Shafie, 2014). An M-Score of higher than -2.22 indicates a strong likelihood of a firm being a manipulator (Beneish, 1999 as cited in Repousis, 2016; Omar et al., 2014). Using the M-Score model, Beneish (1999) found that the model could accurately identify $76 \%$ of firms that had manipulated their earnings and $17.5 \%$ of companies that had not engaged in manipulation (Beneish, 1999; Omar et al., 2014). Beneish M-Score is an integrated approach to fraud detection and allows users to examine the different parts of a company's performance at the same time (Aris et al., 2013). Companies with high chances of manipulating earnings tend to have low returns in the future as compared to those with low chances of manipulating earnings (Beneish \& Nichols, 2007).

Burgstahler and Dichev (as cited in Kighir et al., 2014) and Degeorge, Patel and Zeckhauser (as cited in Kighir et al., 2014) used distribution of reported earnings and accrual modeling to determine earnings manipulation. Burgstahler and Dichev (as cited Kighir et al., 2014) used cross sectional distribution of earning and found that companies engage in earnings management in order to prevent losses and decreases in their earnings. They identified changes in working capital and cash flow from operations as the two components of earnings that managers use to inflate earnings. 
Degeorge et al. (as cited in Kighir, 2014), Charoenwong (2008) and Patel and Zeckhauser (as cited in Kighir, 2014) studied on management of earnings and found that earnings management is motivated by sustaining current performance, achieving projections of analysts and recording positive profits. They, consequently, reported that earnings falling slightly below these thresholds are manipulated upwards to meet the thresholds whilst earnings substantially below or above the thresholds are reined in, in order to make thresholds more achievable in the future (Charoenwong, 2008; Kighir et al., 2014). The researchers further concluded that threshold for reporting positive profit was dominant in shaping the behavioral tendencies of managers in managing earnings (Kighir et al., 2014).

Eldenburg et al. (2011) and Roychowdhury (2006) used Real Activity Management in detecting earnings manipulation. (Roychowdhury (2006) identified that most studies conducted on earnings manipulation centered on detecting anomalous accruals management whilst those directly detecting earnings manipulation through real activities had primarily focused on investments activities such as research and development expenditure. Examining cost of production, discretionary expenses and cash flow from operations, Roychowdhury (2006) found proof of firms engaging in activities including offering price discounts in order to scale-up their turnovers in the short term, aggressively decreasing expenses, and engaging in overproduction to scale-down cost of goods sold with the aim of improving earnings. He also found that factors such as receivables and inventories, motivation to meet zero earnings, and industry membership influence real activities manipulation. Eldenburg et al. (2011) contributed to the research on earnings manipulation through operating activities by providing in-depth understanding of the types of expenditure that are affected by earnings manipulation. Using a sample of Californian non-profit hospitals, they found that expenses on non-operating activities and activities which do not generate revenues declined in hospitals with motivation to engage in earnings management, while activities relating to core patient care remained the same. They additionally found earnings manipulation in non-core operating expenses and provided evidence that firms use real operating expenditure to achieve earnings management.

Whilst some researchers have developed and used other models for detection of earnings manipulation, others have made comparison between different models in terms of their effectiveness (Aghghaleh et al., 2016; Namazi, 2015; Noor, Sanusia, Heang, \& Isa, 2015). Namazi and Maharluie (2015) and Xu and Taylor (2017) compared the effectiveness of the Linear Regression model to two neural networks' models- the Multi-Layer Perception and Generalized Regression Neural Network using 94 public firms on the Tehran Stock Exchange for the period 2003-2011. The researchers found the difference between the abilities of regression model and neural networks models to predict earnings management to be negligible. However, the researchers advised participants in the capital market to use neural networks' models in the analysis of earnings management instead of linear regression. Noor, Sanusia, Heang, Iskandar, and Isa (2015) undertook a research to find out whether fraud motives, opportunities and free cash flow are related to earnings management using 230 firm years on selected companies listed on Bursa Malaysia for 2009 and 2010. Using regression analysis, Noor et al. (2015) found that accrual earnings management is significantly 
constrained by dividend, audit quality and free cash flow suggesting that accruals earnings management is limited by high audit fees. $\mathrm{Xu}$ and Taylor (2017), on the hand, conducted a study the cost of using stock purchase plan as earnings management tool applying Tobit regression model on quarterly data from all publicly listed U.S firms from 2000 to 2010. They found that on the average, companies repurchase shares when share price levels are relatively low compared to the intrinsic value of the share. However, this consideration has no significant relationship with the actual repurchase transactions of the companies using stock repurchase as earnings management. Aghghaleh et al. (2016) studied the abilities of Beneish M-score model and Dechow's F-score models to determine financial statement fraud in Malaysian companies and concluded that both models were effective in predicting financial statement fraud with average accuracy of $73.17 \%$ and $76.22 \%$ respectively. Dichev et al. (2016) used a sample of 400 CFOs to find out the meaning and drivers of earnings quality in view of occurrence and detection of earnings manipulation. In this research, absence of one-time items, sustainability, and backing by actual cash flows were found to be key features of earnings quality. They also found that $20 \%$ of companies deliberately engage in earnings misrepresentation even though they are not breaching the Generally Accepted Accounting Principles (GAAP), citing economic magnitude of the misrepresentation to be $10 \%$ of reported earnings on the average.

Research on the application of Beneish M-score in detention of earnings manipulation has been widely conducted in different geographical areas around the globe (Beneish et al., 2013; Beneish, Lee, \& Nichols, 2011; Nwoye et al., 2013; Repousis, 2016). These researchers have either tested the effectiveness of the Beneish M-score model in detecting earnings manipulation or used the model to determine an existence and a degree of earnings manipulation (Beneish et al., 2013; Beneish, Lee, \& Nichols, 2011; Nwoye et al., 2013). Beneish et al. (2011) found new evidence on the ability of forensic accounting to effectively detect corporate fraud and predict stock returns. Using Beneish M-score model, Beneish et al. (2011) found that 12 out of 17 non-manipulators between 1998 and 2002 were detected by the model, indicating $71 \%$ success rate. They further found that the Beneish M-score model has a strong ability in predicting stock return out-of-sample. Nwoye et al. (2013) on the other hand, investigated how SAS 99 had contributed to the improvement of auditors' skills in Nigeria and the extent that Beneish M-score model could be used to further increase the probability of detecting fraud in financial statements. Using 100 respondents and audited reports from five most capitalized Nigerian manufacturing firms, the researchers found that with the use of secondary and primary data, Beneish M-score model could compliment SAS 99 to contribute immensely to the prevention and detection of fraud by auditors in Nigeria. Beneish et al. (2013) investigated the association between earnings manipulation and expected returns and found firms characterized with higher likelihood of manipulation to exhibit "lower returns on every decile portfolio sorted by size, book-to-market, momentum, accruals, and short interest" (p. 57). Goel (2014) also used Beneish M-score model to investigate probability of earnings management in Indian companies and found existence of earnings management in them.

Other researchers who have conducted research using Beneish M-score model are Filip and Raffournier (2014), Repousis (2016) and Amoa-Gyarteng (2014). Filip and Raffournier (2014) 
studied the effect of the global financial meltdown in 2008-2009 on European listed organizations' behavior in respect of earnings management and found a significant dip in earnings management during the crisis years. Filip and Raffournier (2014) also found a relationship between the economic growth rate and earnings manipulation and reported the tendency of national characteristics to affect earnings management. Whilst Filip and Raffounier (2014) investigated earnings manipulation using M-score on European listed companies, Repousis (2016) used the same model to determine the incidence of creative accounting or propensity of firms to manipulate their earnings using a sample of 25,468 companies from Greece. Repousis (2016) found that 33\% of the total sample displayed signals of manipulation. Repousis (2016) also found that manipulators' days' sales in receivable index (DSRI), leverage index (LVGI), asset quality index (AQI), selling, general and administrative expenses index (SGAI), depreciation index, and total accruals to total assets index (TATA) were significant at 99\% confidence level in their effect on Beneish M-score model. Repousis (2016) further provided evidence that there is a significant relation between earnings management, as represented by Beneish M-score model and DSRI, AQI, GMI, SGI, SGAI and LVGI, with DSRI responsible for $95.92 \%$ of the changes in Beneish M-score model. Amoa-Gyarteng (2014) applied the Beneish M-score model to detect the possibility of earnings manipulation in Anglogold Ashanti Ltd, a listed company in Ghana, from 2010 to 2012. Amoa-Gyarteng (2014) found no sign of earnings manipulation engaged by the company. The researcher's study was, however, limited to only one out of about 41 listed companies which made the sample size inadequately representative.

In addition, Tarjo and Herawati (2015), Chongsirithitisak (2015) and Anh and Linh (2016) have conducted research using Beneish M-score in other parts of the world. Tarjo and Herawati (2015) tested the ability of Beneish M-score model in detecting earnings manipulation using fraud data released by the Financial Services Authority in Indonesia from 2001 to 2014. Tarjo and Herawati (2015) found the model to be effective in detecting earnings manipulation. The researchers explained that whilst gross margin index, depreciation index, selling and general administrative expenses and total accruals showed statistical significance in detecting financial fraud, sales index, asset quality index, and leverage index were statistically insignificant in detecting financial fraud. Chongsirithitisak (2015) applied Beneish M-score model to investigate early signals of earnings manipulation by comparing six (6) listed films on the Thailand Stock Exchange accused of engaging in creative accounting from 2003 and 2011 by the Thailand SEC and eighty-one (81) listed companies in the same industry as those accused. He found $64.59 \%$ of the companies accused of creative accounting portrayed early warning signals as postulated by the model and cited days' gross margin index, sales in receivables index, sales growth asset quality index, except for accruals to total assets, as the warning signals of the creative accounting. Using the Beneish M-score model to detect earning manipulation amongst 229 companies listed in Vietnamese from 2013 to 2014, Anh and Linh (2016) found that $48.4 \%$ of the sample size engaged in earnings manipulation. The effectiveness of Beneish M-model in determining earnings manipulation were confirmed by Anh and Linh (2016), Ahmed and Naima (2016) in their studies in Vietnam and Bangladesh respectively. 


\section{Methodology}

This section discusses the research methodology applied to conduct the research. This includes discussions on the purpose of the study, research design, research questions and hypotheses, population and sampling strategy, research instrument, data collection procedures and data analysis. The research methodology used to conduct this research is quantitative in nature. This quantitative methodology was used to determine the possibility of earnings manipulation amongst 22 firms listed on the GSE using their published financial statements from 2011 to 2016. This research also sought to investigate the relationship between earnings manipulation, as measured by Beneish M-score and share price. The research analysis was based on an extensive literature review covering the history of the Ghana Stock Exchange, the theory of Beneish M-score model and its application on different stock exchanges across the world, other theories for detection of earnings manipulation, as well as the conclusions made so far within the global space.

\subsection{Purpose of the Study}

The purpose of this quantitative research was to investigate whether non-banking and finance firms listed on the GSE engaged in earnings manipulation from 2011 to 2016. The purpose was to detect existence of earnings manipulation among such listed companies and to determine if small listed companies engaged in earnings manipulations more than their big counterparts. In addition, this quantitative research intended to determine the relationship between earnings manipulation, as measured by M-Score, and share prices of sampled listed companies. The results would help in making informed investment decisions, protect investors and promote the soundness and stability of the Ghanaian stock market.

\subsection{Research Design}

The quantitative research methodology was applied on data gathered from the financial statements and share prices published in the companies' annual reports, Ghana Stock Exchange website and Annual Reports Ghana website. The three models applied for this research were Beneish M-score, Mann-Whitney U test and Spearman's correlation analysis.

\subsubsection{Beneish M-Score Model}

The existence of earnings manipulation amongst the sampled 22 listed companies were tested with Beneish M-score model. According to Beneish (1999), Chadha (2016) and Mahama (2015), the Beneish M-score model is calculated with data from financial statements for the detection of earnings manipulation. The M-score model formula used is:

$\mathrm{M}=-4.84+(0.92 * \mathrm{DSRI})+(0.528 * \mathrm{GMI})+(0.404 * \mathrm{AQI})+(0.892 * \mathrm{SGI})+(0.115 * \mathrm{DEPI})-$ $(0.172 * \mathrm{SGAI})+(4.679 *$ TATA $)-(0.327 * \mathrm{LVGI})$

Where:

- DSRI (Days' Sales in Receivables Index) $=\left(\right.$ Net Receivables t $_{t} /$ Sales $\left._{t}\right) /$ Net Receivables $_{\mathrm{t}-1} /$ Sales $_{\mathrm{t}-1}$ ). The DSRI is calculated by dividing days' sales in receivables in current year (t) by days' sales in receivables in previous year (t-1) (Beneish, 1999; 
Jun, 2014). A large increase in DSRI could be indicative of revenue inflation;

- GMI (Gross Margin Index $)=\left[\left(\right.\right.$ Sales $_{t-1}-$ Cost of Goods Sold $\left._{t-1}\right) /$ Sales $\left._{t-1}\right] /\left[\left(\right.\right.$ Sales $_{t}-$ Cost of Goods Sold $_{t}$ ) / Sales $t$. Gross Margin Index is calculated by dividing gross margin in the previous year $(\mathrm{t}-1)$ by the gross margin in the current year $(\mathrm{t})$. GMI above 1 signifies deterioration in gross margin (Beneish, 1999; Nwoye et al., 2012; McLeavey, 2013; Repousis, 2016; Anh \& Linh, 2016)

- AQI (Asset Quality Index $)=\left[1-\left(\right.\right.$ Current Assets $_{t}+$ Plant, Property \& Equipment E $_{t}+$ Securities $\left._{\mathrm{t}}\right) /$ Total Assets $\left._{\mathrm{t}}\right] /\left[1-\left(\left(\right.\right.\right.$ Current $_{\text {Assets }}$ $_{\mathrm{t}-1}+$ Plant, Property \& Equipment $_{\mathrm{t}-1}+$ Securities $_{\mathrm{t}-1}$ ) / Total Assets $\left.\mathrm{t}_{-1}\right)$ ]. This is the ratio of non-current assets other than plant, property and equipment to total assets. It is the ratio of asset quality in the current year (t) to asset quality in the previous year (t-1) (Beneish, 1999; Nwoye et al., 2012; McLeavey, 2013; Repousis, 2016; Anh \& Linh, 2016);

- SGI (Sales Growth Index $)=$ Sales $_{t} /$ Sales $_{t-1}$. This refers to the ratio of sales in year $t$ to sales in year t-1. Sales growth is not itself a measure of manipulation. However, growth firms are likely to find themselves under pressure to manipulate in order to keep up appearances (Beneish, 1999; Nwoye et al., 2012; McLeavey, 2013; Repousis, 2016; Anh \& Linh, 2016);

- DEPI (Depreciation Index $)=\left(\right.$ Depreciation $_{t-1} /\left(\right.$ Plant, Property \& Equipment $_{t-1}+$ Depreciation $\left.\left._{t-1}\right)\right) /\left(\right.$ Depreciation $_{t} /\left(\right.$ Plant, Property \& Equipment $_{t}+$ Depreciation $\left._{t}\right)$ ). This is a measure of the ratio of the rate of depreciation in previous year $(\mathrm{t}-1)$ to the corresponding rate in the current year $(\mathrm{t})$. DEPI more than 1 indicates that assets are being depreciated at a slower rate. This suggests that the firm might be revising useful asset life assumptions upwards, or adopting a new method that is income friendly (Beneish, 1999; Nwoye et al., 2012; McLeavey, 2013; Repousis, 2016; Anh \& Linh, 2016);

- SGAI (Sales, General and Administrative Expenses Index) $=($ Selling General \& Administrative Expense $_{\mathrm{t}} /$ Sales $_{\mathrm{t}}$ ) / (Selling General \& Administrative Expense $\mathrm{t}_{\mathrm{t}-1} /$ Sales $\left.t_{-1}\right)$. This is a measure of ratio of SGA expenses in the current year $(t)$ relative to the previous year ( $\mathrm{t}-1$ ) (Beneish, 1999; Nwoye et al., 2012; McLeavey, 2013; Repousis, 2016; Anh \& Linh, 2016)

- LVGI (Leverage Index $)=\left[\left(\right.\right.$ Current Liabilities $_{t}+$ Total Long-Term Debt $\left._{t}\right) /$ Total Assets $\left._{\mathrm{t}}\right] /$ [(Current Liabilities $\mathrm{t}_{\mathrm{t}-1}+$ Total Long-Term Debt $\left._{\mathrm{t}-1}\right) /$ Total Assets $\left.\mathrm{t}_{\mathrm{t}-1}\right]$. This refers to the ratio of total debt to total assets in current year $(\mathrm{t})$ relative to the previous year (t-1). An LVGI of more than 1 is an indication of a rise in leverage;

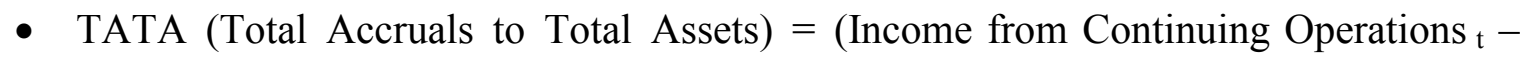
Cash Flows from Operations ${ }_{t}$ ) / Total Assets t.

- $\mathrm{t}$ is the current year; and

- $\quad \mathrm{t}-1$ is the previous year (Anh \& Linh, 2016; Beneish, 1999; McLeavey, 2013; Nwoye et al., 2012; Repousis, 2016) 
An M-Score of lower than -2.22 indicates that the firm will not be a manipulator whilst an M-Score of higher than -2.22 signals that the company is likely to be a manipulator (Beneish, 1999; Chadha, 2016; Mahama, 2015).

In order to test the hypotheses, $\mathrm{H}_{01}$ and $\mathrm{H}_{\mathrm{A} 1}$, the existence of earnings manipulation was determined by calculating the percentages of companies that engaged in earning manipulation on annual and annual average basis based on the companies' M-scores computed. In this context, any manipulation level above zero percent $(0 \%)$ was deemed to mean that some listed companies had engaged in earnings manipulation and therefore resulted in the acceptance of $\mathrm{H}_{\mathrm{A} 1}$ and rejection of $\mathrm{H}_{01}$. On the contrary, manipulation level of zero percent $(0 \%)$ resulted in the acceptance of $\mathrm{H}_{01}$ and rejection of $\mathrm{H}_{\mathrm{A} 1}$.

\subsubsection{Mann-Whitney U test}

With regard to the testing of hypotheses $\mathrm{H}_{02}$ and $\mathrm{H}_{\mathrm{A} 2}$, the percentages of engagement in earnings manipulation by the two groups of companies (small companies and big companies) for the period 2011-2016 were tested for statistically significant difference with Mann-Whitney U Test using Statistical Package for Social Sciences (SPSS) software version 16 (Weaver et al., 2018). Mann-Whitney U test is used to determine whether two independent sample drawn from the same populations have statistically significant difference (Carver \& Nash, 2009). It is used to compare the mean of two independent samples (Gravetter \& Wallnau, 2017). The Mann-Whitney $U$ test is applied when the number of measures of two groups is below 20 (Corder \& Foreman, 2011). The Mann-Whitney U is calculated as follows:

$$
U=n_{1} n_{2}+\frac{n_{2}\left(n_{2}+1\right)}{2}-\sum_{i=n_{1}+1}^{n_{2}}\left(R_{i}\right)
$$

where:

$U=$ Mann-Whitney $U$ test,

$n_{1}=$ sample size one,

$n_{2}=$ sample size one, and

$\Sigma R_{i}=$ sum of the ranks from the sample of interest (Corder \& Foreman, 2011; Gravetter \& Wallnau, 2017; Hollander, Wolfe, \& Chicken, 2013). The Mann-Whitney U test uses p value to interpret the statistically significant difference between two independent groups based on a certain significance level (Gravetter \& Wallnau, 2017). The p value refers to the lowest level of significance at which the null hypothesis can be rejected (Hollander et al., 2013). The level of significance is defined as the probability of rejecting a null hypothesis that is actually true (Rovai, Baker, \& Poton, 2014). For the purpose of this research, a level of significance of 0.05 was used. According to Singh (2007), the level of significance is normally set to a level of 0.05 in social research. A p-value less or equal to 0.05 is an indication of strong evidence against the null hypothesis and so the null hypothesis is rejected. A p-value greater than 0.05 is a demonstration of weak evidence against the null hypothesis and therefore the researcher fails to reject the null hypothesis (Rovai, Baker, \& Poton, 2014). 


\subsubsection{Spearman's Correlation Analysis}

The nature of the relationship between share price and M-score (earnings manipulation) was determined using Spearman's correlation analysis. The Spearman's correlation analysis was also conducted on earnings manipulation and share prices separately on small and big companies to determine whether they have different correlations. Spearman's correlation analysis is a non-parametric methodology used to determine the strength of direction of relationship that exists between two variables (Elliott \& Woodward, 2014). This analysis generates the correlation coefficient and p-value. The p-value is compared with the level of significance in order to determine the statistical significance of a relationship between two variables (Hollander et al., 2013). This correlation coefficient is represented by $\rho$ and it is statistically represented by the formula:

$$
\rho=1-\frac{6 \sum d_{i}^{2}}{n\left(n^{2}-1\right)}
$$

Where $d_{i}$ is differences in ranks of corresponding variables and $\mathrm{n}$ is the number of observations (Matthews \& Kostelis, 2011) Spearman's correlation coefficient values always range between -1 and +1 . A correlation coefficient of +1 indicates that two variables have a perfect positive association, a correlation coefficient of -1 indicates that two variables have a perfect negative association, and a correlation coefficient of 0 indicates that there is no association between the two variables (Cohen \& Cohen, 2013). P-value is the likelihood that the null hypothesis will be mistakenly rejected (Verma, 2013; Schneiter, 2008 as cited in Loveland, 2014). The p-value generated using Statistical Package for Social Sciences (SPSS) software version 16 was compared to level of significance to determine the statistical significance of the association between share price and earnings manipulation. A p-value less than the level of significance indicated that there was a statistically significant association between two variables and acceptance of the null hypothesis. On the other hand, a p-value greater than the level of significance denoted statistically insignificant association between two variables and a rejection of the null hypothesis. (Elliott \& Woodward, 2014). A level of significance of 0.05 was used for this research.

\subsection{Population and Sampling Strategy}

Research population refers the entire group of objects, events or individuals that a researcher intends to focus on for the purpose of a scientific enquiry (Stocks \& Wall, 2014). Since it is practically impossible to study each individual in a population, researchers apply sampling strategies to select a subset of the population, test the sample and make conclusions and generalization (Harrison \& Callan, 2013; Wang, 2014). The problem of limited resources encountered by researchers has also been cited as a major reason that has necessitated sampling (Emmel, 2013). According to Rees (2011), sampling strategies refer to issues concerning which individuals, objects or events from the population to be included in a research sample and the alternative techniques to be used to undertake the selection. It is however, critical to ensure that the sample size is well representative to warrant scientific query and to ensure acceptable generation (Speight, 2015). The overall population size for 
this research is 41 companies listed on the GSE. This quantitative research applied purposive sampling and stratified sampling strategies. The choice of the two sampling strategies was based on the purpose of the study, the methodology as well as the financial and accounting data required. Purposive sampling strategy was used for the selection of the general sample size. This accounted for the exclusion of banking and finance related listed companies from the research. Purposive sampling technique is a sampling method in which researchers endeavor to select a sample that is representative based on their opinion or purpose (Rainbolt \& Dwyer, 2012; Roy, Acharya, \& Roy, 2016). According to Emmel (2013), "the theoretical or purposive sampling strategies assume that to explain real phenomena requires more than faithful abstracted rendering of events and experiences" (p. 45). On the other hand, the stratified sampling strategy was used for the grouping into small and big companies. Stratified sampling technique is a sampling method in which the targeted population is divided into two or more groups according to one or more characteristics common to them (Levy \& Lemeshow, 2013).

Based on the purposive sampling strategy, twenty-two (22) non-banking and finance listed organizations on the GSE were used, representing $63 \%$ of the population size of 41 listed companies. The sample size of 22 is sufficient because out of total population size of 41,17 listed companies were banking and finance related ones such as banks and insurance companies. These 17 companies were excluded as a result of type of methodology applied. Some financial data required to calculate M-scores for these 17 companies were nonexistent due to the nature of their operations and financial reporting. Thus, the 22 companies represented $92 \%$ of the companies whose financial data were compatible with the methodology applied. The exclusion of the two non-banking and finance companies, Samba Foods Limited and Sam Woode Limited, from this quantitative research was due to lack of adequate financial data. The assessment period was 2011-2016.

\subsection{Research Instrument}

Research instruments refer to measurement tools designed to collect data on a phenomenon targeted for scientific enquiry (Creswell, 2014). However, this study did not require any research instrument since only secondary data were used. The study used financial data obtained from audited annual reports of the sampled companies and retrieved from the companies' websites, the GSE website and Annual Reports Ghana website.

\subsection{Instrument Validation}

Research instruments are measurement tools designed to gather data on a phenomenon targeted for scientific investigation (Creswell, 2014). Data gathering would be impossible without a research instrument (Seliger \& Shohamy, 2013). The two criteria for measuring research instruments are validity and reliability (Sobrepena, n.d.). Instrument validation refers to the process applied to confirm that the instrument being employed for a particular test is appropriate for its intended use (Zumbo \& Chan, 2014). Validity "refers the degree to which evidence and theory support the interpretations of test scores entailed by proposed uses of tests" (The Standards for Educational and Psychological Testing, 2002 as cited in Park, 2012, p. 54). "Instrument validation typically precedes (conceptually and temporarily) the 
assessment of internal and statistical conclusion" (Straub, 1989 as cited Sidorova, Evangelopoulos, Torres, \& Johnson, 2013, p. 12). Assessing the usefulness and suitability of a test does not only require numerous sources, but also, adequate proof must be adduced to support the test for that purpose (Chadha, 2016). In addition, evaluation test validity is a process and not an event. Therefore, a continuous procedure is required (Chadha, 2016). A reliable instrument provides similar data when applied at different period on the same group (O’Dwyer \& Bernauer, 2014). In this quantitative research, only secondary data were used. The secondary data used were gathered from audited annual report of the sampled companies sourced from credible institutions such as GSE amongst others. The secondary data gathered were also suitable for the models used in this quantitative research as the original application was based on audited financial data. The use of audited financial data to detect earnings manipulation using M-score model has been validated by Beneish (1999), Chongsirithitisak (2015) and Repousis (2016). The audited financial data used were reliable because they had been screened by the regulatory authorities in Ghana such as Securities and Exchange Commission and the GSE using similar universally accepted auditing principles and practices.

\subsection{Data Collection Procedures}

Data source and type used for this quantitative research were all secondary in nature. The data were gathered from the annual reports and financial statements from the company websites, as well as websites of Ghana Stock Exchange and Annual Report Ghana for the period 2011-2016. The data type and source were consistent with and appropriate for the methodology applied for the study.

\subsection{Data Analysis}

The quantitative methodology used the financial data collected to compute Beneish M-score of the sampled listed companies for each year using excel generated formula. The researcher analyzed the M-scores computed for the sampled listed companies to determine whether they were involved in manipulating their earnings, what percentage of sampled companies were engaged in earnings manipulation during the period under review, and which type of company, engaged more in earnings manipulation. This analysis was done using pie charts and narratives to explain existence of earnings manipulation in sampled listed companies. The Beneish M-score model and Mann-Whitney $U$ test were used to test the following hypotheses:

$\mathrm{H}_{01}$ : No listed companies in Ghana engage in earnings manipulation

$\mathrm{H}_{\mathrm{A} 1}$ : Some listed companies in Ghana engage in earnings manipulation.

$\mathrm{H}_{02}$ : Small companies listed on the GSE do not manipulate their earnings more than big companies listed on the GSE.

$\mathrm{H}_{\mathrm{A} 2}$ : Small companies listed on the GSE manipulate their earnings more than big companies listed on the GSE.

The quantitative methodology also applied Spearman correlation analysis, using SPSS 16 
software, to investigate the association between the M-scores computed from the sampled listed companies and their year-end share prices. Results generated were interpreted using tables, charts and narratives in order to confirm the null hypotheses adduced or otherwise. Thus, the Spearman correlation analysis methodology was used to test the hypotheses:

$\mathrm{H}_{03}$ : Share price is not related to M-Score.

$\mathrm{H}_{\mathrm{A} 3}$ : Share price is related to $\mathrm{M}-\mathrm{Score}$

\section{Data and Empirical Results}

\subsection{Introduction}

This section covers demographic statistics, detailed analysis of data gathered, empirical findings from the data analysis and summary of the results. The data used in this section were gathered from the sampled companies' financial statements $f$ Tables and pie charts were used to respond to the research questions and the hypotheses indicated in the preceding sections.

\subsection{Demographic Statistics}

The research sample was grouped into small and big companies to facilitate data analysis. The categorization of sampled twenty-two (22) companies into small and big companied was based on their total assets as at end of the 2016 accounting year. The choice of the 22 sampled companies was based on the compatibility of the methodology used in this study. The remaining companies were financial institutions whose financial data did not allow for the application of the M-score model. For the purpose of this quantitative research, all companies with total assets less than GHC50 million as at the end of 2016 accounting year were classified as small companies whilst those with total assets of more than GHC50 million at the end of same accounting year were considered as big companies. Based on this assumption., eight companies were classified as small companies whilst fourteen (14) were classified as big companies as follows:

- Small Companies

- African Champion Industries Limited

- Ayton Drugs Manufacturing Limited

- Clydestone (Ghana) Limited

- Golden Web Limited

- Pioneer Kitchenware Limited

- Starwin Products Limited

- Transol (Ghana) Limited

- Camelot Ghana Limited

- Big Companies 
- Aluworks Limited

- AngloGold Ashanti Limited

- Benso Oil Palm Plantation Limited

- Cocoa Processing Company Limited

- Fam Milk Limited

- Guinness Ghana Breweries Limited

- Ghana Oil Company Limited

- Gold Star Resources Limited

- Mechanical Lloyd Company Ltd

- Produce Buying Company Limited

- PZ Cussons Ghana Limited

- Tullow Oil Plc

- Total Petroleum Ghana Limited

- Unilever Ghana Limited.

Upon the computation of the M-scores, average percentage was used to determine which group engaged more in earnings manipulation from 2011 to 2016. In addition, Mann-Whitney test was conducted to test the statistical significance of the level of earnings manipulation between the two groups of companies. The yearly M-scores of these sampled companies were computed using Beneish M-score model (Beneish, 1999). 


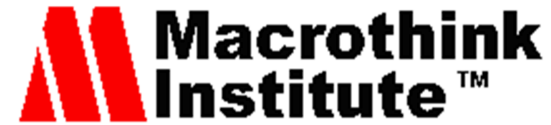

Table 3. Beneish M-Scores of sampled listed companies in Ghana from 2011-2016

\begin{tabular}{llllllll}
\hline Company Name & 2011 & 2012 & 2013 & 2014 & 2015 & 2016 & $\begin{array}{l}\text { Percentage of earnings } \\
\text { manipulation }\end{array}$ \\
\hline African Champion Industries Ltd & N/A & 2.30 & -3.06 & -10.1 & N/A & N/A & $33 \%$ \\
Aluworks Ltd & -4.17 & -2.52 & -3.11 & -1.50 & -2.97 & -4.01 & $17 \%$ \\
Anglogold Ashanti Limited & -1.63 & -2.92 & -3.07 & -4.64 & -3.58 & -3.01 & $17 \%$ \\
ADMCL & -2.24 & -1.48 & -2.56 & -3.66 & -2.60 & -2.53 & $17 \%$ \\
Benso Oil Palm Plantation Ltd & -3.27 & -3.01 & -2.54 & -0.94 & -2.11 & -2.85 & $33 \%$ \\
Camelot Ghana Limited & -2.74 & -2.67 & -3.38 & -2.71 & -2.57 & -3.14 & $0 \%$ \\
Clydestone (Ghana) Limited & N/A & -3.21 & -4.48 & -3.07 & -3.10 & 0.20 & $20 \%$ \\
Cocoa Processing Company & -1.72 & -3.34 & -3.80 & N/A & N/A & N/A & $33 \%$ \\
Fan Milk Limited & N/A & N/A & N/A & -3.28 & -3.50 & -1.75 & $33 \%$ \\
Guinness Ghana Breweries Ltd & -1.75 & -8.61 & -3.29 & -1.72 & -2.49 & -3.91 & $33 \%$ \\
Ghana Oil Company Limited & -2.66 & -2.59 & -2.53 & -2.97 & -2.03 & -2.45 & $17 \%$ \\
Gold Star Resources Ltd & -3.13 & -2.52 & -3.52 & -7.34 & -4.05 & -2.47 & $0 \%$ \\
Golden Web Ltd & -2.85 & 15.84 & -2.70 & -3.67 & 4.00 & -1.87 & $50 \%$ \\
Mechanical Lloyd Company Ltd & -2.20 & -2.35 & -1.43 & -2.99 & -2.86 & -3.05 & $33 \%$ \\
Produce Buying Company Ltd & -0.31 & -5.20 & -1.15 & -5.06 & -2.55 & -2.72 & $33 \%$ \\
Pioneer Kitchenware Ltd & 3.49 & 5.69 & -0.38 & -6.33 & 22.15 & -2.28 & $67 \%$ \\
PZ Cussons Ghana Ltd & -4.00 & -2.46 & -2.93 & -2.02 & -1.02 & -1.61 & $50 \%$ \\
Starwin Products Limited & -2.11 & -8.54 & -3.15 & -2.77 & -3.31 & -3.20 & $17 \%$ \\
Tullow Oil Plc & -1.89 & -3.21 & -2.86 & -4.08 & -3.84 & -2.83 & $17 \%$ \\
Total Petroleum Ghana Limited & -1.77 & -2.73 & -2.09 & -2.76 & -2.33 & -2.74 & $33 \%$ \\
Transol Solutions (Ghana) Ltd & N/A & N/A & N/A & N/A & N/A & N/A & N/A \\
Unilever Ghana Limited & -2.56 & -1.88 & -3.22 & -3.08 & -2.54 & -3.20 & $17 \%$ \\
\hline & & & & & & & \\
& & & & & & \\
& & & & & & \\
& & & & &
\end{tabular}

Table 3 shows the sampled listed companies' M-scores from 2011-2016. The portions stated N/A means Not Applicable and was as a result of the researcher's inability to calculate the Beneish M-score due to lack of the appropriate financial data to calculate the Asset Quality Index (AQI), a component of the Beneish M-score formulae. This arose from the fact that the total assets were made up of only plant, property and equipment and current assets either before the previous year or the following year, without any other fixed or long-term assets. This occurred in 5 companies out of a total of 22 companies sampled between 2011 and 2016 as shown in Table 3. Transol Solutions (Ghana) Limited's M-scores could not be calculated for this reason in all the six years under study whilst that of Fan Milk Limited could not be calculated from 2011 to 2013. African Champion Industries Limited was also affected in 2011 and 2015 whilst Clydestone (Ghana) Limited and Cocoa Processing Company's M-scores could not be calculated in 2011 and 2014 respectively for the same reason. There was no data available for African Champion Industries Limited in 2016 and Cocoa Processing in 2015 and 2016. Therefore, a total of $116 \mathrm{M}$ scores was calculated from 2011 to 2016 as shown in Table 3. 


\section{1ll Macrothink}

\subsection{Details of Analysis and Results}

Details of analysis and results are discussed in four (4) parts as follows:

a) Analysis of $\mathrm{M}$ score results by year;

b) Analysis of the M-scores results for the entire period (2011-2016)

c) Analysis of M-scores results based on number of occurrences (2011-2016)

d) Analysis of correlation analysis results on M-scores and share prices (2011-2016)

\subsubsection{Analysis of M Scores Results by Year}

From the 22 companies studied in 2011, the researcher was able to calculate M-scores of 18 companies as shown in Table 3. Out of the 22 companies, M-scores of 4 companies could not be computed because their total assets were the same as the sum of their individual current assets and property, plant, and equipment, making it impossible for their Asset Quality Indices to be calculated. Out of the 18 companies whose M-scores could be calculated, 13 were big companies and 5 were small companies.

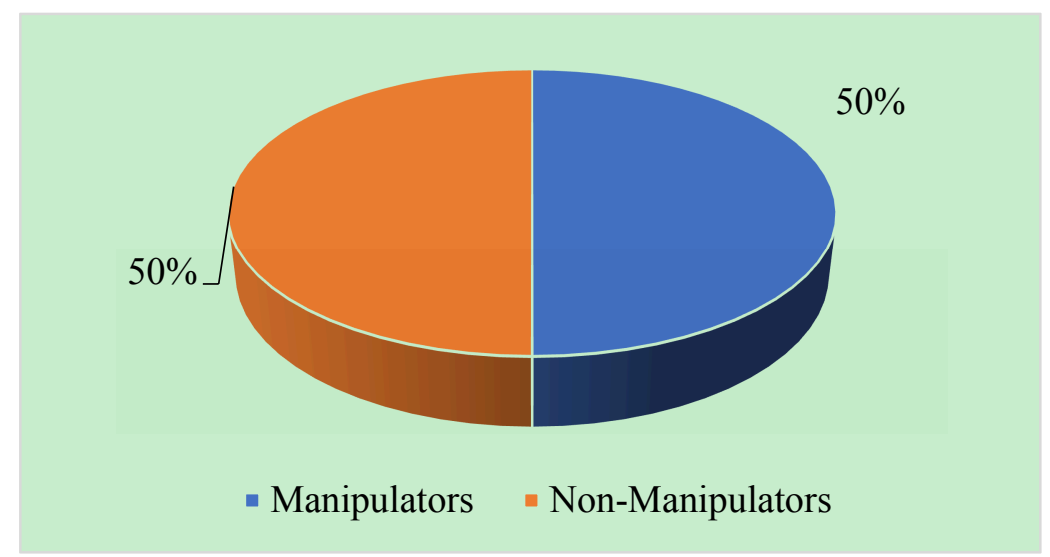

Figure 3. Companies Status based on M-Scores in 2011

Figure 3 is an illustration of the status of the sampled companies based on their M-Scores in 2011 and it showed that out of 18 whose M-scores could be calculated, 9 companies representing 50\% engaged in earning manipulation whilst the remaining 9 representing 50\%, were found not to have engaged in such practices. Out of the total of 9 companies found to have engaged in creative accounting, 7 companies, representing $77.8 \%$ of them were big companies whilst 2 companies, representing $22.2 \%$ of them, were small companies. In all $53.8 \%$ of the 13 big companies whose M-scores could be calculated were found to be involved in earnings manipulation in 2011 as compared to $40 \%$ of the total 5 small companies whose M-scores could be computed. Since the level of earnings manipulation in 2011 was above zero percent $(0 \%)$, the Null Hypothesis that no listed companies in Ghana engage in earnings manipulation, $\mathrm{H}_{01}$, is therefore untrue and should be rejected in favor of the 
Alternative Hypothesis, $\mathrm{H}_{\mathrm{A} 1}$.

In 2012, 20 out of 22 companies' M-scores were calculated. M-scores of 2 sampled companies could not be determined due to inability to compute their Asset Quality Index, arising from the equality between total assets on one hand, and current assets, property, plant and equipment on the other hand. Out of the 20 companies whose M-scores could be determined, 13 were big companies and 7 were small companies.

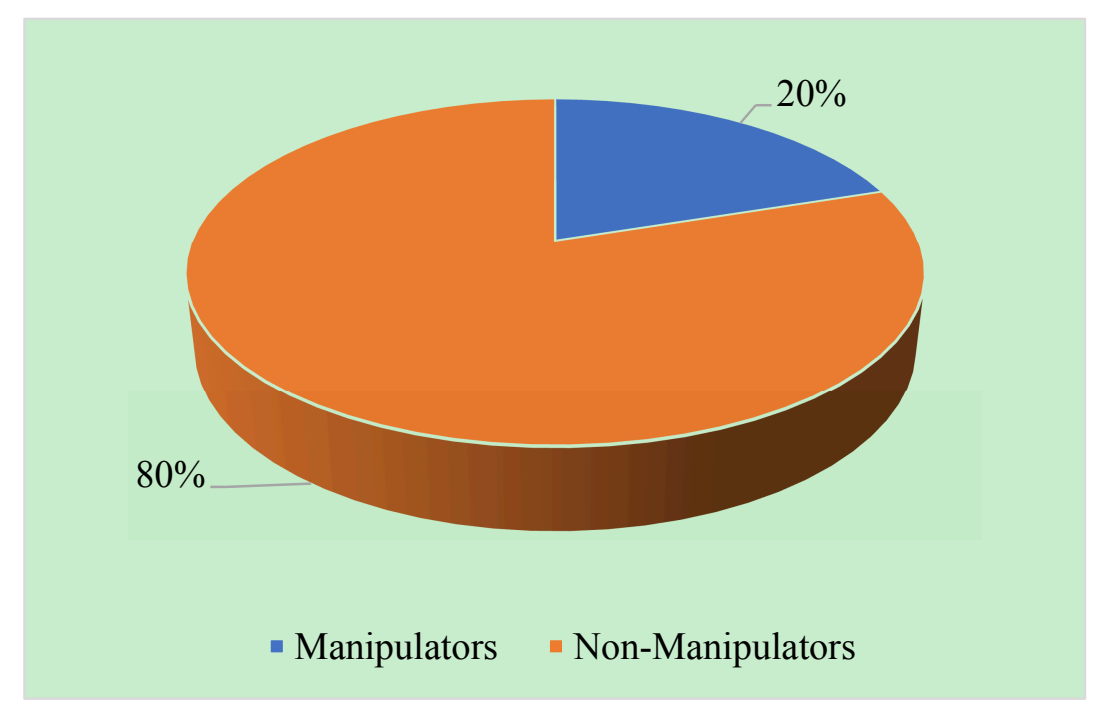

Figure 4. Companies Status based on M-Scores in 2012

Out of the 20 companies whose M-scores could be determined, 20\% (4 companies) was found to have engaged in earnings manipulations with $80 \%$ (16 companies) considered as non-manipulators based on their M-scores computed as shown in Figure 4. Out of the 4 companies found to be earnings manipulators, $75 \%$ (3 companies) were small companies whilst the remaining 25\% (1 company) was a big company. In addition, $42.9 \%$ of the 7 small companies whose M-scores could be determined in 2012 were found to have engaged in creative accounting as compared to $7.7 \%$ of the 13 big companies whose M-scores could be computed in 2012. The result indicates that the level of earnings manipulation in 2012 was above zero percent $(0 \%)$. As a result, the Null Hypothesis that no listed companies in Ghana engage in earnings manipulation, $\mathrm{H}_{01}$, is therefore untrue and should be rejected in favor of the Alternative Hypothesis, $\mathrm{H}_{\mathrm{A} 1}$.

In 2013, 20 out of 22 companies' M-scores were calculated. The M-scores of 2 companies could not be calculated due to the equality between total assets on one other and current assets, property, plant and equipment on the other hand, making it impossible for the Asset Quality Indices to be calculated. Out of the 20 companies whose M-scores could be determined, 13 were big companies and 7 were small companies. 


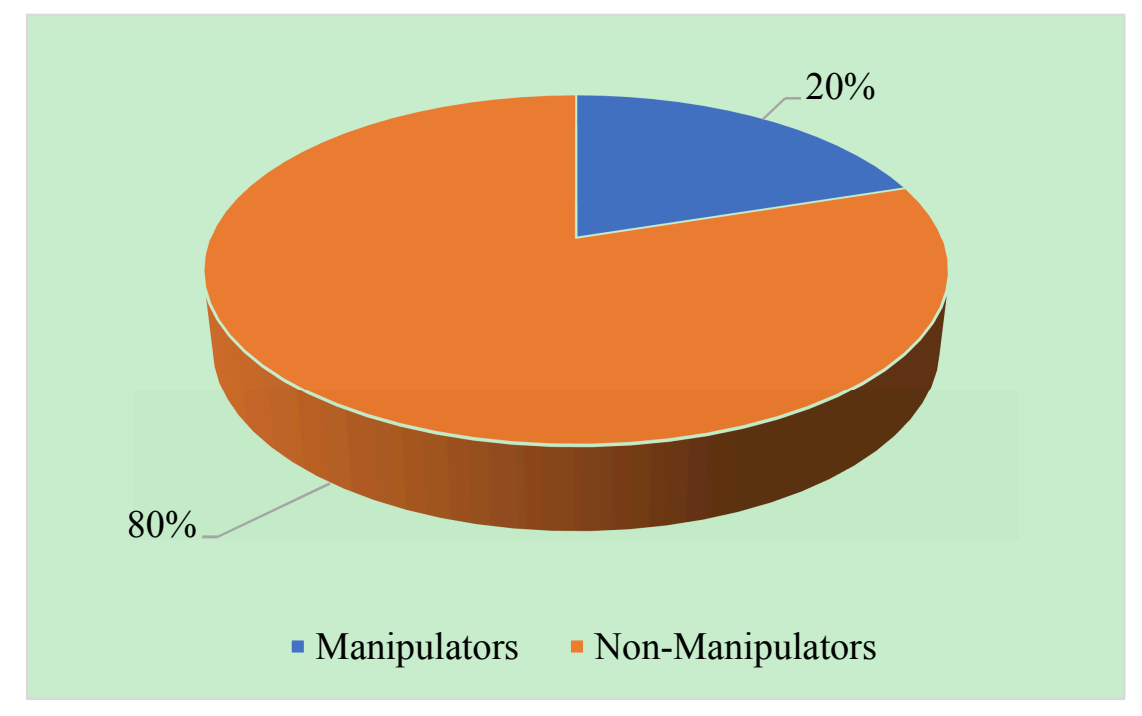

Figure 5. Companies Status based on M-Scores in 2013

Out of these 20 companies, 4 companies representing 20\%, were found to have engaged in earnings manipulations or creative accounting whilst 16 companies or $80 \%$ did not as presented in Figure 5. Based on the total of 4 manipulators, 25\% ( 1 company) was a small company whilst $75 \%$ (3 companies) were big companies. In all, 14.3\% of 7 small companies was involved in creative accounting in 2013 whilst the remaining $85.7 \%$ were not. On the hand, $23.1 \%$ of the 13 big companies in 2013 manipulated their earnings whilst the remaining $76.9 \%$ did not engage in such practice. Since the level of earnings manipulation in 2013 was above zero percent $(0 \%)$, the Null Hypothesis that no listed companies in Ghana engage in earnings manipulation, $\mathrm{H}_{01}$, is therefore untrue and rejected in favor of the Alternative Hypothesis, $\mathrm{H}_{\mathrm{A} 1}$.

In 2014, M-scores of 20 out of 22 companies were calculated. The M-scores of 2 companies could not be computed because total assets were made up of only property, plant and equipment and current assets, therefore Asset Quality Indices could not be calculated (Marinakis, 2011). 


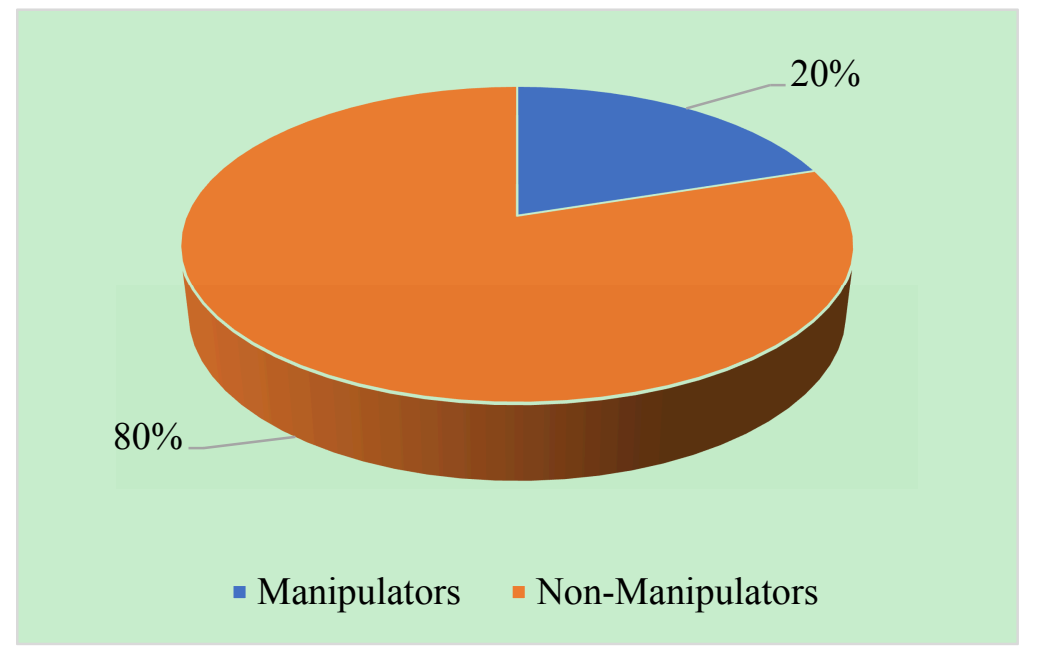

Figure 6. Companies Status based on M-Scores in 2014

Out of the 20 companies whose M-scores were calculated, 7 were small companies and 13 were big companies. The results show that $20 \%$ of the 20 companies or 4 companies were found to have been involved in creative accounting whilst $80 \%$ or 16 companies were considered not have been involved in such practice as shown in Figure 6. All the 4 companies found to have manipulated their earning in 2014 were big companies and they represented $30.8 \%$ of the 13 big companies whose M-scores could be determined. The result shows that the level of earnings manipulation in 2014 was above zero percent $(0 \%)$. Therefore, the Null Hypothesis that no listed companies in Ghana engage in earnings manipulation, $\mathrm{H}_{01}$ is untrue and rejected in favor of the Alternative Hypothesis, $\mathrm{H}_{\mathrm{A} 1}$.

In 2015, the researcher could calculate M-scores of 19 out of the total 22 companies analyzed. Out of the remaining 3 companies whose M-scores could not be ascertained, 2 companies had their total assets equal to current assets, property, plant and equipment, making impossible for the Assets Quality Indices to be calculated, and 1 company had no financial data available. The 19 companies whose M-scores could be computed consisted of 5 small companies and 14 big companies. 


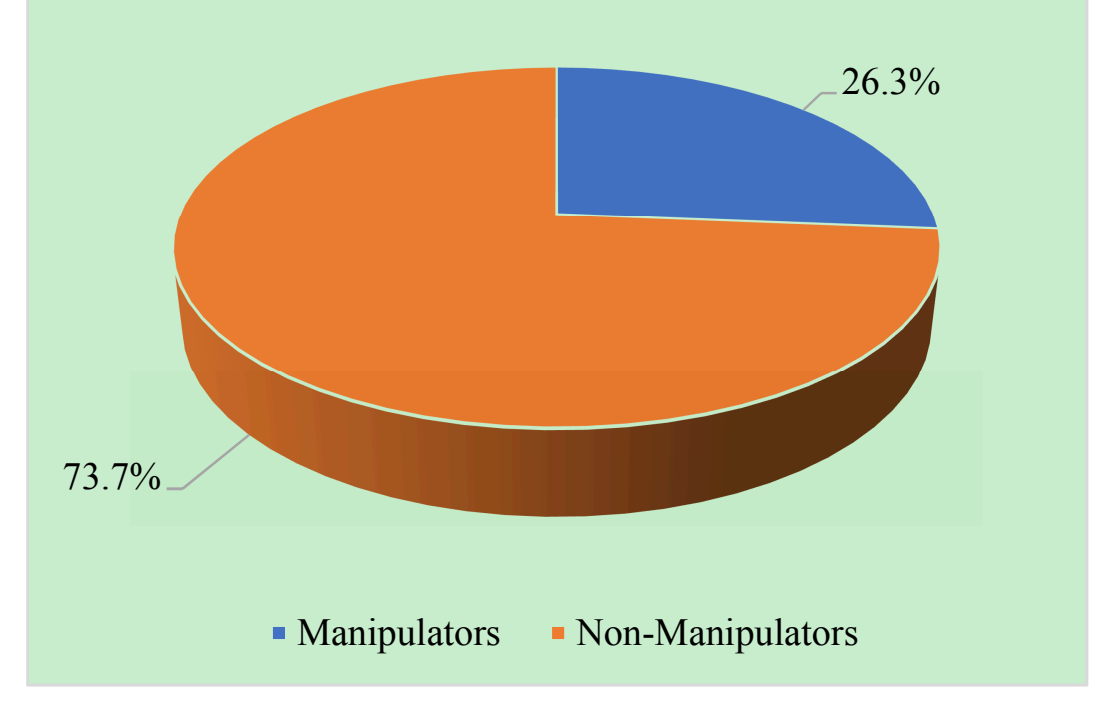

Figure 7. Companies Status based on M-Scores in 2015

Figure 7 shows that out of these 19 companies analyzed in 2015, 26.3\% (5 companies) were found to have engaged in earnings manipulation whilst $73.3 \%$ (14 companies) did not involve in such practice. With the 5 manipulators, $40 \%$ were small companies whilst $60 \%$ were big companies. $40 \%$ of 5 small companies whose M-score could be determined were found to have manipulated their earnings in 2015 whilst $60 \%$ were considered not be earnings manipulators. Regarding the 14 big companies whose M-scores could be computed in 2015, $21.4 \%$ were found to have manipulated their earnings whilst the remaining $78.6 \%$ did not engage in such practice. As demonstrated in the above results, the level of earnings manipulation in 2015 was above zero percent $(0 \%)$. Consequently, the Null Hypothesis that no listed companies in Ghana engage in earnings manipulation, $\mathrm{H}_{01}$, is untrue and is rejected in favor of the Alternative Hypothesis, $\mathrm{H}_{\mathrm{A} 1}$.

In 2016, M-scores of 19 companies could be calculated out of the 22 companies sampled and those of 3 companies could not be computed. Out of the remaining 3 companies whose M-scores could not be computed, 2 companies had their total assets equal to current assets, property, plant and equipment, thus the Assets Quality Indices could not be calculated whilst 2 companies had no financial data available. Out of the 19 companies whose M-scores were calculated, 6 were small companies and 13 was a big company. 


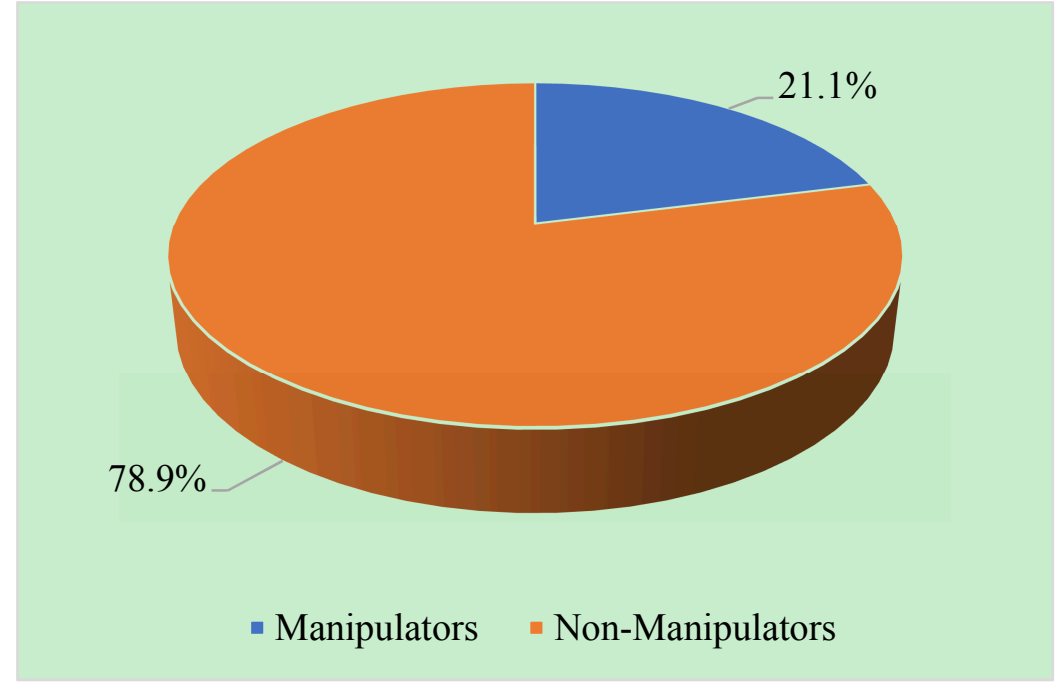

Figure 8. Companies Status based on M-Scores from 2016

As depicted in Figure 8, out of the 19 companies whose M-scores were computed in 2016, $21.1 \%$ (4 companies) were found to have manipulated their earnings with $78.9 \%$ (15 companies) being non-manipulators. Out of 4 manipulators, $50 \%$ or 2 companies were small companies and $50 \%$ or 2 companies were big companies. $33.3 \%$ ( 2 companies) of 6 small companies whose M-scores were calculated were found to have manipulated their earnings in 2016 whilst the remaining $66.7 \%$ were not considered as manipulators. With regard to the 13 companies whose M-scores could be computed and analyzed in 2016, 15.4\% (2 companies) were found to have engaged in creative accounting whilst the remaining $84.6 \%$ (11 companies) did not engage in earnings manipulations. Since the level of earnings manipulation in 2016 was above zero percent $(0 \%)$, the Null Hypothesis that no listed companies in Ghana engage in earnings manipulation, $\mathrm{H}_{01}$, is untrue and is rejected in favor of the Alternative Hypothesis, $\mathrm{H}_{\mathrm{A} 1}$.

4.3.2 Analysis of the M-Scores Results for the Entire Period (2011-2016)

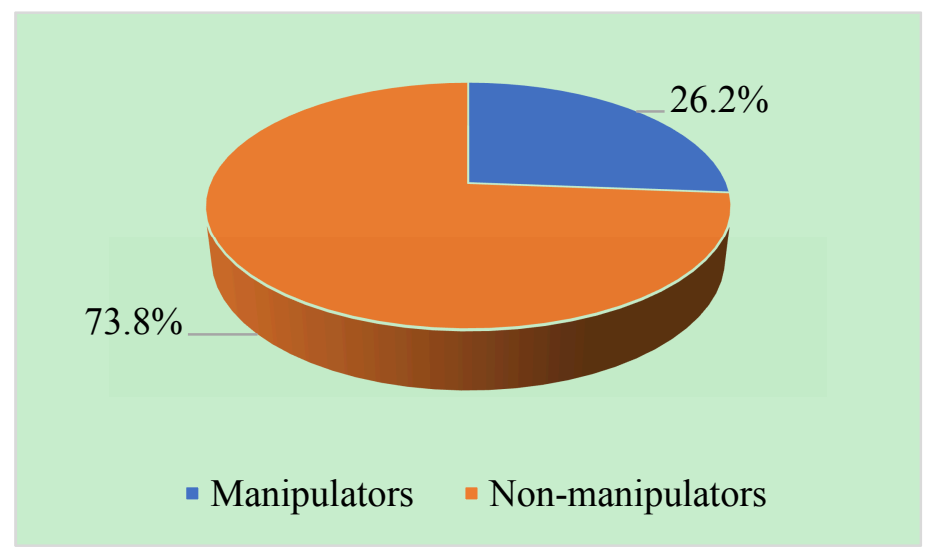

Figure 9. Companies Status based on M-Scores from 2011-2016 


\section{Macrothink}

Based an average of approximately19 companies whose M-scores were determined and analyzed between 2011 and 2016, 26.2\% on the average were involved in creative accounting whilst $73.8 \%$ were not involved in such practice as shown in figure 9. The result indicates that the level of earnings manipulation over the period 2011-2016 was above zero percent $(0 \%)$. As a result, the Null Hypothesis that no listed companies in Ghana engage in earnings manipulation, $\mathrm{H}_{01}$, is untrue and is rejected in favor of the Alternative Hypothesis, $\mathrm{H}_{\mathrm{A} 1}$.

Regarding the size of companies, big companies were found to be have engaged in earnings manipulation more than small companies on the average over the entire period 2011 to 2016.

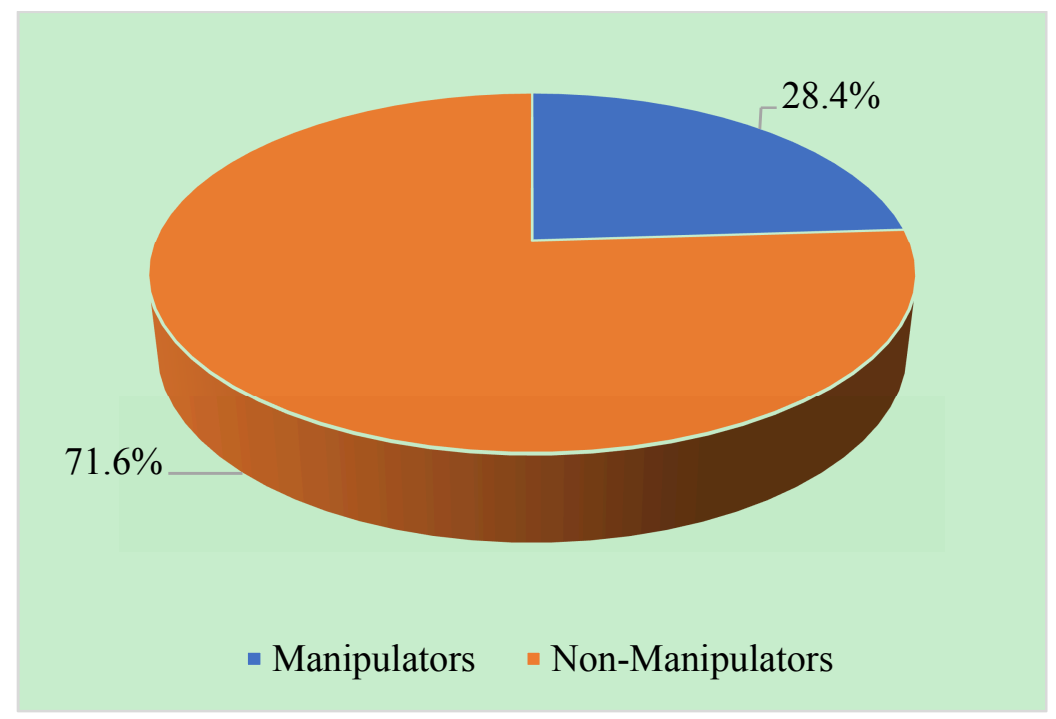

Figure 10. Status of Small Companies (2011-2016)

Based on an average of 6 small companies whose M-scores could be determined and analyzed between 2011 and 2016, an average of $28.4 \%$ engaged in creative accounting whilst $71.6 \%$ did not involve in such activity as shown in figure 10 .

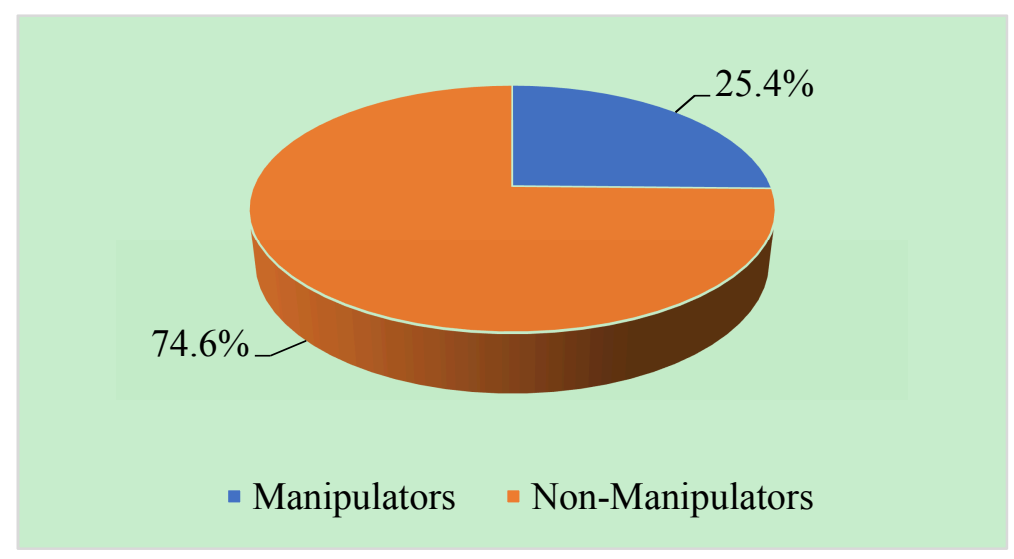

Figure 11. Status of big Companies (2011-2016) 


\section{Macrothink Institute ${ }^{\mathrm{TM}}$}

On the hand, out of an average of 13 whose M-scores could be computed and analyzed for the period 2011 o 2016, an average $25.4 \%$ were involved in creative accounting whilst $74.6 \%$ were not involved in such practice as depicted in figure 11. In terms of average percentages between 2011-2016, small companies engaged more in earnings manipulation more than their big counterparts.

In order to test for statistical significance with regard to engagement in earnings manipulation by company size and make conclusion on Hypotheses, $\mathrm{H}_{02}$ and $\mathrm{H}_{\mathrm{A} 2}$, Mann-Whitney non-parametric variable analysis test was conducted.

Table 4. Descriptive Statistics of the Mann-Whitney U Test

\begin{tabular}{|c|c|c|c|c|c|c|c|c|}
\hline & \multirow[t]{2}{*}{$\mathrm{N}$} & \multirow[t]{2}{*}{ Mean } & \multirow{2}{*}{$\begin{array}{l}\text { Std. } \\
\text { Deviation }\end{array}$} & \multirow[t]{2}{*}{ Minimum } & \multirow[t]{2}{*}{ Maximum } & \multicolumn{3}{|c|}{ Percentiles } \\
\hline & & & & & & 25 th & $\begin{array}{l}\text { 50th } \\
\text { (Median) }\end{array}$ & 75 th \\
\hline earnings_manipulation & 21 & 27.1429 & 16.05081 & .00 & 67.00 & 17.0000 & 33.0000 & 33.0000 \\
\hline company size & 21 & 1.6667 & .48305 & 1.00 & 2.00 & 1.0000 & 2.0000 & 2.0000 \\
\hline
\end{tabular}

The result of the Mann-Whitney test is presented in Tables 4, 5, 6, 7 and 8 . The mean rank in Table 5 shows that small companies engaged more in earnings manipulation than big companies since the mean rank of small companies was 11.21 compared to that of big companies of 10.89 . 


\section{Macrothink}

Table 5. Mean Ranks of the Mann-Whitney U Test

\begin{tabular}{lllll}
\hline & company_size & N & Mean Rank & Sum of Ranks \\
\hline earnings_manipulation & small companies & 7 & 11.21 & 78.50 \\
& big companies & 14 & 10.89 & 152.50 \\
& Total & 21 & & \\
\hline
\end{tabular}

Table 6. Test Statistics ${ }^{\mathrm{b}}$ of the Mann-Whitney U Test

\begin{tabular}{ll}
\hline & earnings_manipulation \\
\hline Mann-Whitney U & 47.500 \\
Wilcoxon W & 152.500 \\
Z & -.117 \\
Asymp. Sig. (2-tailed) & .907 \\
Exact Sig. [2*(1-tailed Sig.)] & $.913^{\mathrm{a}}$ \\
\hline
\end{tabular}

a. Not corrected for ties.

b. Grouping Variable: company_size

The test statistics in Table 6 shows p-value of 0.907 which is greater than the level of significance of 0.05 . This indicates that there is no evidence to support a statistically significant difference between the level of earnings manipulation of small companies and that of big companies $(U=47.500, p=0.907)$.

Table 7. Case Processing Summary of the Mann-Whitney U Test

\begin{tabular}{lllllll}
\hline & \multicolumn{2}{l}{ Cases } & & & & \\
& Included & & Excluded & \multicolumn{3}{c}{ Total } \\
\hline & $\mathrm{N}$ & Percent & $\mathrm{N}$ & Percent & $\mathrm{N}$ & Percent \\
earnings_manipulation * & 21 & $95.5 \%$ & 1 & $4.5 \%$ & 22 & $100.0 \%$ \\
company_size & & & & & & \\
\hline
\end{tabular}

Table 8. Median Report of the Mann-Whitney U Test

\begin{tabular}{ll}
\hline company_size & earnings_manipulation \\
\hline small companies & 20.0000 \\
big companies & 33.0000 \\
Total & 33.0000 \\
\hline
\end{tabular}


Therefore, the Null Hypothesis that small companies listed on the GSE do not manipulate their earnings more than big companies listed on the GSE, $\mathrm{H}_{02}$, is accepted while the Alternative Hypothesis, $\mathrm{H}_{\mathrm{A} 2}$ is rejected.

\subsubsection{Analysis of M-Scores Results Based on Number of Occurrences (2011-2016)}

The total number of M-scores calculated for the 21 companies between 2011 and 2016 was 116. Out of the $116,31 \mathrm{M}$-scores were found to denote earnings manipulation whilst 85 M-scores did not denote manipulation.

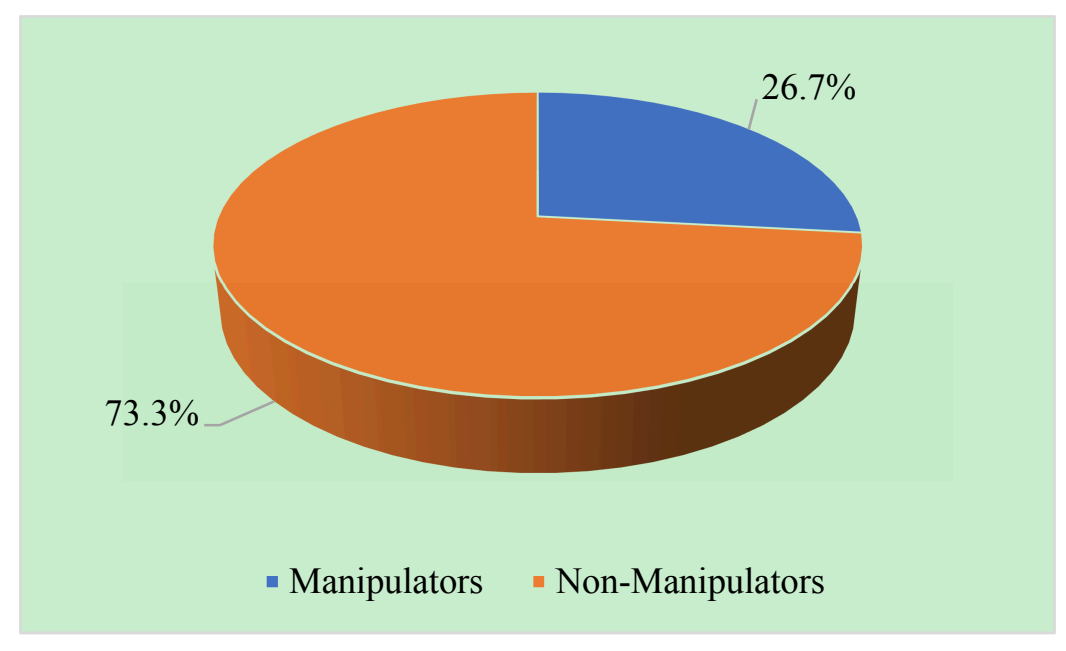

Figure 12. Status of companies based on manipulation of occurrences from 2011-2016

Figure 12 shows that $73.3 \%$ (85 M-scores) of 116 signified non manipulators whilst $26.7 \%$ depicted evidence of creative accounting. Since some of listed companies were found to have manipulated their earnings from 2011 to 2016, the Null Hypothesis that no listed companies in Ghana engage in earnings manipulation, $\mathrm{H}_{01}$, is therefore untrue and is rejected. The Alternative Hypothesis, $\mathrm{H}_{\mathrm{A} 1}$ is therefore accepted.

Figure 13 presents a trend analysis of level of manipulation from 2011 to 2016 based on the sampled companies. 


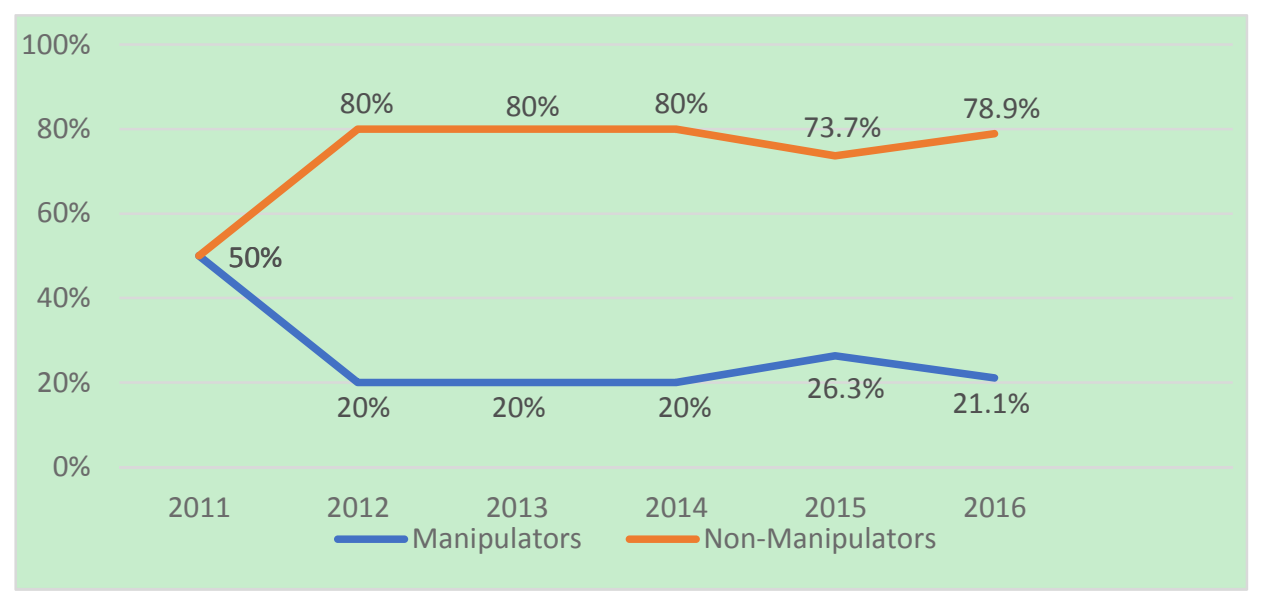

Figure 13. Trend Analysis of the status of companies based on M-scores.

The result presented in Figure 13 is a confirmation that some listed companies in Ghana engaged in earnings manipulation with the level of manipulation ranging from $20 \%-50 \%$ over the period 2011-2016. In this regard, a rejection of the Null Hypothesis that no listed company in Ghana engage in earnings manipulation, $\mathrm{H}_{01}$, in favor of the Alternative Hypothesis that some listed companies in Ghana engage in earnings manipulation, $\mathrm{H}_{\mathrm{A} 1}$.

\subsubsection{Analysis of Correlation Analysis Results on M-Scores and Share Prices (2011-2016)}

Table 9 presents the outcome of the Spearman correlation analysis on the M Scores and Share Prices of the sampled companies using SPSS software 16. The average share prices over the period 2011-2016 and the percentage of earning manipulation of each company over the same period were used for the Spearman correlation analysis.

Table 9. Spearman's correlation analysis results between earnings manipulation (M Score) and Share Price of the entire Sample

\begin{tabular}{|c|c|c|c|c|}
\hline & & & Earnings_Manipulation & Share_Price \\
\hline \multirow[t]{11}{*}{ Spearman's rho } & Earnings_Manipulation & Correlation & 1.000 & -.268 \\
\hline & & Coefficient & & \\
\hline & & Sig. (2-tailed) & . & .240 \\
\hline & & & 21 & 21 \\
\hline & & $\mathrm{N}$ & & \\
\hline & & & -.268 & 1.000 \\
\hline & Share_Price & Correlation & & \\
\hline & & Coefficient & & \\
\hline & & & .240 & . \\
\hline & & Sig. (2-tailed) & & \\
\hline & & $\mathrm{N}$ & 21 & 21 \\
\hline
\end{tabular}




\section{Macrothink}

International Finance and Banking

ISSN 2374-2089

2020, Vol. 7, No. 1

A Spearman's correlation coefficient of -0.268 shows that there is a weak negative relation between earnings manipulation and share price in Table 9. Since the p-value of 0.240 generated as shown in Table 9 is greater than the assumed level of significance of 0.05 , there is no statistically significant association between earnings manipulation and share price. Consequently, the Null Hypothesis that Share price is not related to M-Score, $\mathrm{H}_{03}$, is true and accepted and the Alternative Hypothesis, $\mathrm{H}_{\mathrm{A} 3}$, is rejected.

Table 10. Spearman's correlation analysis results between earnings manipulation (M Score) and share price for small companies

\begin{tabular}{llllc}
\hline & & Earnings_Manipulation & Share_Price \\
\hline Spearman's rho & Earnings_Manipulation & Correlation & 1.000 & -.318 \\
& & Coefficient & & \\
& & Sig. (2-tailed) &. & .487 \\
& & 7 & 7 \\
Share_Price & $\mathrm{N}$ & -.318 & 1.000 \\
& Correlation & & \\
& Coefficient & & \\
& Sig. (2-tailed) & .487 & 7 \\
\hline
\end{tabular}

The results of Spearman correlation analysis in Table 10 also shows that there is a weak negative relationship between earnings manipulation and share price $(\rho=-0.318)$ and statistically insignificant relationship between the two variables when conducted only on small companies since the p-value of 0.487 is greater than the assumed level of significance of 0.05 .

Table 11. Spearman's correlation analysis results between earnings manipulation (M Score) and share price for big companies

\begin{tabular}{lllll}
\hline & & Earnings_Manipulation & Share_Price \\
\hline Spearman's rho & Earnings_Manipulation & Correlation & 1.000 & -.315 \\
& & Coefficient & & \\
& & Sig. (2-tailed) &. & .272 \\
& & $\mathrm{~N}$ & 14 & 14 \\
& & & 1.000 \\
& Share_Price & Correlation & -.315 & \\
& Coefficient & &. \\
& Sig. (2-tailed) & .272 & 14 \\
& $\mathrm{~N}$ & 14 &
\end{tabular}




\section{Ml Macrothink}

International Finance and Banking

ISSN 2374-2089

2020, Vol. 7, No. 1

A similar analysis performed on only big companies generated a Spearman's correlation coefficient of -0.315 and p-value of 0.272 as shown in Table 11, indicating a weak negative association between earnings manipulation and share price and statistically insignificant relationship between the two variables since the $p$-value is greater than the assumed level of significance of 0.05 .

\section{Discussion}

\subsection{Summary of the Results}

The results from the Beneish M-score model indicated that $50 \%$ of the sampled companies were likely to have engaged in earnings manipulation in 2011, 20\% in 2012, 2013 and 2014, $26.3 \%$ in 2015 and $21.1 \%$ in 2016 . The results also showed that the biggest drop in creative accounting occurred between 2011 and 2012. Additionally, the results indicated that with the exception of 2011, minority of the sampled companies were found to have manipulated their earnings.

Table 12. Results of the Analysis of M-scores for the entire sampled companies from 20112016

\begin{tabular}{|c|c|c|c|c|c|c|c|}
\hline & 2011 & 2012 & 2013 & 2014 & 2015 & 2016 & Average \\
\hline Manipulators & $50 \%$ & $20 \%$ & $20 \%$ & $20 \%$ & $26.3 \%$ & $21.1 \%$ & $26.2 \%$ \\
\hline Non-Manipulators & $50 \%$ & $80 \%$ & $80 \%$ & $80 \%$ & $73.7 \%$ & $78.9 \%$ & $73.8 \%$ \\
\hline $\begin{array}{l}\text { H01: No listed companies } \\
\text { in Ghana do not engage in } \\
\text { earnings manipulation }\end{array}$ & Rejected & Rejected & Rejected & Rejected & Rejected & Rejected & Rejected \\
\hline $\begin{array}{l}\text { HA1: Some listed } \\
\text { companies in Ghana } \\
\text { engage in earnings } \\
\text { manipulation }\end{array}$ & Accepted & Accepted & Accepted & Accepted & Accepted & Accepted & Accepted \\
\hline
\end{tabular}

Table 12 shows that since some companies in the research sample engaged in earnings manipulation from 2011 to 2016, the Null Hypothesis that no listed companies in Ghana engage in earnings manipulation, $\mathrm{H}_{01}$, was rejected in favor of the Alternative Hypothesis, $\mathrm{H}_{\mathrm{A} 1}$. Table 12 also shows that the average percentage of companies that engaged in creative accounting over the period 2011-2016 stood at $26.2 \%$ as compared to that of non-manipulators of $73.8 \%$. As a result, the Null Hypothesis that no listed companies engage in earnings manipulation, $\mathrm{H}_{01}$, was rejected and the Alternative Hypothesis, $\mathrm{H}_{\mathrm{A} 1}$ was accepted. 
Table 13. Results of the M-score Analysis based on Size of Company from 2011-2016

\begin{tabular}{|c|c|c|c|c|c|c|c|c|c|c|c|c|c|c|}
\hline & \multicolumn{2}{|c|}{$\overline{\vec{i}}$} & \multicolumn{2}{|c|}{$\stackrel{\sim}{\stackrel{\sim}{\sim}}$} & \multicolumn{2}{|c|}{$\stackrel{m}{\stackrel{n}{N}}$} & \multicolumn{2}{|c|}{ 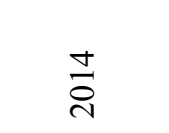 } & \multicolumn{2}{|c|}{$\bar{i}$} & \multicolumn{2}{|c|}{$\overline{\mathrm{N}}$} & \multicolumn{2}{|c|}{ 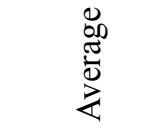 } \\
\hline בे: & $\begin{array}{l}\overline{\overline{\widetilde{U}}} \\
\text { फ }\end{array}$ & .00 & $\begin{array}{l}\overline{\bar{G}} \\
\text { क् }\end{array}$ & .00 & $\begin{array}{l}\overline{\bar{\Xi}} \\
\text { w }\end{array}$ & .000 & $\begin{array}{l}\overline{\overline{\widetilde{U}}} \\
\text { फ }\end{array}$ & .000 & $\begin{array}{l}\overline{\bar{\varpi}} \\
\text { फ }\end{array}$ & .000 & $\begin{array}{l}\overline{\bar{g}} \\
\text { क }\end{array}$ & .000 & $\begin{array}{l}\overline{\overline{\text { I }}} \\
\text { की }\end{array}$ & $\stackrel{\circ 0}{m}$ \\
\hline 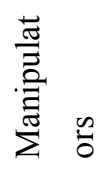 & $\begin{array}{l}\stackrel{0}{0} \\
\dot{+} \\
\dot{+}\end{array}$ & $\begin{array}{l}\stackrel{0}{\infty} \\
\hat{n}^{-}\end{array}$ & $\begin{array}{l}\stackrel{\circ}{ } \\
\text { f }\end{array}$ & $\stackrel{\circ}{\stackrel{2}{ }}$ & $\stackrel{\text { ஸे }}{\text { ஸे }}$ & $\frac{\circ}{\vec{\lambda}}$ & ठें & $\begin{array}{l}\stackrel{0}{0} \\
\infty \\
0 \\
0\end{array}$ & $\begin{array}{l}\stackrel{0}{0} \\
\dot{0} \\
\dot{+}\end{array}$ & $\frac{\stackrel{\circ}{+}}{\dot{\nabla}}$ & $\begin{array}{l}\stackrel{0}{m} \\
m \\
m\end{array}$ & $\begin{array}{l}\stackrel{\circ}{+} \\
\stackrel{+}{n}\end{array}$ & $\begin{array}{l}\stackrel{\circ}{+} \\
\stackrel{\sim}{d}\end{array}$ & $\begin{array}{l}\stackrel{\circ}{+} \\
\ddot{\sim}\end{array}$ \\
\hline 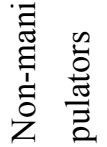 & $\begin{array}{l}80 \\
\dot{8} \\
8\end{array}$ & 犬ें & $\frac{\stackrel{0}{\frac{1}{n}}}{i n}$ & $\begin{array}{c}\stackrel{0}{ } \\
\text { aू }\end{array}$ & $\begin{array}{l}\stackrel{0}{2} \\
\infty \\
\infty\end{array}$ & $\begin{array}{l}\stackrel{\circ}{\circ} \\
\text { }\end{array}$ & $\begin{array}{l}\stackrel{0}{0} \\
\dot{8}\end{array}$ & $\begin{array}{l}\stackrel{0}{0} \\
\stackrel{0}{0}\end{array}$ & $\begin{array}{l}80 \\
\dot{8} \\
8\end{array}$ & $\begin{array}{l}\stackrel{0}{0} \\
\infty \\
\infty\end{array}$ & $\begin{array}{l}\stackrel{0}{8} \\
\stackrel{8}{8}\end{array}$ & $\begin{array}{l}\dot{0} \\
\dot{\infty} \\
\dot{0}\end{array}$ & $\frac{\dot{b}}{i}$ & $\begin{array}{l}\stackrel{0}{0} \\
\text { ṫ }\end{array}$ \\
\hline
\end{tabular}

As depicted in Table 13, the percentages of small companies that were involved in creative accounting were more than those of big companies in 2012, 2015 and 2016. The figures were $42.9 \%$ in respect of small companies as compared to $7.7 \%$ for big companies in $2012,40 \%$ for small companies as against $21.4 \%$ for big companies in 2015 and $33.3 \%$ for small companies as compared to $15.4 \%$ for big companies in 2016 as shown in Table 13. On the other hand, the percentage of big companies that engaged in earning manipulation was more than that of small companies in 2011, 2013 and 2014. The results show that the percentage of big companies that engaged in earnings manipulation were $53.8 \%$ as compared to $40 \%$ of small companies in 2011 and $23.1 \%$ as compared to $14.3 \%$ of small companies in 2013 . No small company was involved in earnings manipulation in 2014 . However, $30.8 \%$ of big companies were involved in earnings manipulation in 2014. The average percentage of small companies that manipulated their earnings during the period entire period 2011-2016 was $28.4 \%$ as compared to $25.4 \%$ for big companies. The Mann-Whitney U Test analysis conducted showed that there was no statistically significant difference between the level of earnings manipulation amongst small and big companies since the p-value of 0.907 generated was greater than the level of significance of 0.05. Consequently, the Null Hypothesis that small companies listed on the GSE do no manipulate their earnings more than big companies listed on the GSE, $\mathrm{H}_{01}$, was accepted and the Alternative Hypothesis, $\mathrm{H}_{\mathrm{A} 1}$ was rejected.

With reference to a total of $116 \mathrm{M}$-scores calculated for the period 2011-2016, the percentage of manipulation occurrences stands at $26.3 \%$ as compared to that of non-manipulation of $73.7 \%$. In general, the results demonstrated some level of earnings manipulation amongst the sampled listed company. Furthermore, on the average the percentage of small companies that engaged in earnings manipulation over the entire period 2011-2016 was less than that of big companies. Therefore, the Null Hypothesis that no listed companies in Ghana engage in earnings manipulation, $\mathrm{H}_{01}$, was rejected in favor of the Alternative Hypothesis, $\mathrm{H}_{\mathrm{A} 1}$ since 
some listed companies engaged in earnings manipulation.

In relation with the Spearman correlation analysis between earnings manipulation and share price, the percentage of earnings manipulation and average share prices between 2011 and 2016 were used for each variable. The correlation analysis between the two variables conducted on the entire sampled companies produced a Spearman correlation coefficient of -0.268 and $p$-value of 0.240 , showing that there was no statistically significant relationship between share price and earnings manipulation. This is an indication that other factors either than earnings manipulation impact share prices. This resulted in an acceptance of the Null Hypothesis, $\mathrm{H}_{03}$ and a rejection of the Alternative Hypothesis, $\mathrm{H}_{\mathrm{A} 3}$ since the $\mathrm{p}$-value was greater than the level of significance of 0.05 . Analysis of the correlation between earnings manipulation and share price separately for small companies and big companies also showed that there was no statistically significant relationship between the two variables.

\subsection{Discussion of the Results}

In this research, three sets of hypotheses were formulated. These hypotheses were tested using Beneish M-score model, Mann-Whitney U test, Spearman Correlation Analysis respectively. Beneish $\mathrm{M}$-score was used to predict the possibility of earnings manipulation. The criterion scale used was that an M-Score of lower than -2.22 indicated no incidence of earnings manipulation whilst an M-Score of higher than -2.22 was an indication of incidence of earnings manipulation. Correlation coefficient was used to predict the relationship between earnings manipulation, as measured by M-score, and share prices. The criterion scale used was that a Spearman correlation coefficient of +1 indicated that two variables had a perfect positive association, a Spearman correlation coefficient of -1 indicated that two variables had a perfect negative association, and a Spearman correlation coefficient of 0 indicated that there was no association between the two variables. In addition, p-value greater than the $5 \%$ confidence interval signifies statistically insignificant relationship whilst p-value less than conventional 5\% confidence interval denoted statistically significant relationship. In this part of this section, the main findings of each hypothesis in section four of this research are reviewed, discussed and analyzed in relations to the literature review.

$\mathrm{H}_{01}$ : No listed companies in Ghana do not engage in earnings manipulation

$\mathrm{H}_{\mathrm{A} 1}$ : Some listed companies in Ghana engage in earnings manipulation

The results of the M-scores calculated on yearly basis from 2011 to 2016 and for the entire period indicated that some listed companies engaged in earnings manipulation. On the average, $26.2 \%$ of the 21 companies whose M-scores could be determined were found to have manipulated their earnings, recording the highest figure of 50\% in 2011 and the lowest of $20 \%$ in 2012, 2013 and 2014. For the entire period 2011-2016, the average percentage of companies that manipulated their earnings amounted to $26.2 \%$. In terms of total M-scores of 116 computed, $73.3 \%$ signified non manipulation whilst $26.7 \%$ denoted incidence of earnings manipulation. Since some companies were engaged in earnings manipulation on the basis average percentage, the Null Hypothesis that no listed companies in Ghana engage in earnings manipulation, $\mathrm{H}_{01}$, is rejected in favor of the Alternative Hypothesis that some listed 
companies in Ghana engage in earnings manipulation, $\mathrm{H}_{\mathrm{A} 1}$. This finding supports the assertion that $\mathrm{M}$-score could accurately identify companies that have manipulated their earning and those that have not engaged in such practice (Beneish, 1999; Beneish et al., 2011; Goel, 2014; Omar et al., 2014). This finding is also consistent with the finding of Dichev et al. (2016) which indicates that some companies deliberately manipulate their earnings even when applying the GAPP. Furthermore, the finding supports the opinion of ACFE (2016) which identifies some level of financial fraud manipulations. Finally, this finding confirms the findings of Repousis (2016) and Anh and Linh (2016) that detected existence of earnings manipulation in their respective targeted stock exchanges. The net fall in earnings manipulation from between 2011 and 2016 supports the findings of Ahmed and Naima (2016).

$\mathrm{H}_{02}$ : Small companies listed on the GSE do not manipulate their earnings more than big companies listed on the GSE.

$\mathrm{H}_{\mathrm{A} 2}$ : Small companies listed on the GSE manipulate their earnings more than big companies listed on the GSE.

The results of the M-score analysis showed that even though percentage of small companies that manipulated their earnings exceeded that that of big companies in 2012, 2015 and 2016, the latter's percentage of earnings manipulation also exceeded that of the former in 2011, 2013 and 2014. However, the average percentage of earning manipulation for small companies which was $28.4 \%$ was more than that of big companies which was $25.4 \%$ for the entire period 2011-2016. However, since the p-value of 0.907 generated with the Mann-Whitney $U$ test was higher than the level of significance of 0.05 , denoting no statistically significant difference, the Null Hypothesis, $\mathrm{H}_{02}$, was accepted against the Alternative Hypothesis that small companies listed on the GSE manipulate their earnings more than big companies listed on the GSE, $\mathrm{H}_{\mathrm{A} 2}$. This finding contradicts the views of Alwan (as cited in Wuryani, 2012); Veronica and Siddharta (as cited in Wuryani, 2012), and Zhu and Lu (2013) who propose a statistically significant negative relationship between earnings manipulation and company size. This finding also contradicts the opinions of Li (as cited in Behrahani and Pajoohi, 2016); Sayari et al. (2013) and Wasila (as cited in Wuryani, 2012) who are proponents of statistically significant positive relationship between earnings manipulation and company size.

$\mathrm{H}_{03}$ : Share price is not related to M-Score.

$\mathrm{H}_{\mathrm{A} 3}$ : Share price is related to M-Score.

The correlation analysis results on the entire sample indicated a Spearman's correlation coefficient of -0.268 and p-value of 0.240 signifying that there was weak negative relationship and statistically insignificant association between earnings manipulation and share prices since the $\mathrm{p}$-value generated was higher than the assumed level of significance of 0.05. Similarly, the Spearman correlation analysis performed separately on small companies and big companies between earnings manipulation and share price showed no statistically significant association between the two variables. In these circumstances, the p-value of the 
small companies and big companies were 0.487 and 0.272 respectively as compared to the assumed level of significance of 0.05 . Therefore, this Null Hypothesis, $\mathrm{H}_{03}$, was accepted against the Alternative Hypothesis $\left(\mathrm{H}_{\mathrm{A} 3}\right)$ that share price is related to $\mathrm{M}$-score. This finding neither supports the argument that earnings manipulation and share price are positively related as put forward by Lufti et al. (2016) and Zhu and Lu (2013) nor the view that the two variables are negatively related as proposed by Beneish (1999), Christianto and Budiharta (2014) and Nuryman (2013) in terms of statistical significance.

\section{Conclusions and Recommendations}

\subsection{Conclusion}

The Beneish M-score model is useful in predicting incidence of earnings manipulation in listed companies in Ghana. However, M-score is only appropriate in predicting possibility of creative accounting in companies whose fixed or long term assets are made up not only property, plant and equipment but others financial items such as long term investments and intangible assets. In a situation where the only fixed asset is property, plant and equipment or total assets are equal to current assets and property, plant and equipment, the Asset Quality Index, which is a major component of the M-score formula cannot be computed or would be undefined. This was demonstrated in computation of M-scores of Transol Solutions Limited, Fan Milk Limited, African Industries Limited, Clydestone (Ghana) Limited and Cocoa Processing Company Limited.

Some listed companies in Ghana were involved in creative accounting on yearly basis from 2011 to 2016 and for the entire period. However, majority of the companies were found not to have involved in earning manipulations on the yearly basis except for 2011 when the percentage was equal to that of the manipulators. On the average, $26.2 \%$ of the companies assessed manipulated their earnings between 2011 and 2016. The rejection of the Null Hypothesis, $\mathrm{H}_{01}$, supports the general views of Beneish et al. (2011), Beneish (1999), Goel (2014) and Omar et al. (2014) that confirm the effectiveness of M-score in detecting earnings manipulation. The finding also suggests that there are a number of companies who have not been detected to have manipulated their earnings by the various stakeholders such as regulatory bodies and auditors and yet have engaged or are engaging in such practice. The earnings manipulation detection models such as M-score provide an effective tool to ensure such companies are found to avoid any negative impact on the financial system as a whole. This finding also confirms that innate desire of companies to deliberately manipulate their earnings for various reasons and the need to constantly check them despite their outward financial performance (ACFE, 2016; Dichev et al., 2016).

During the six-year period (2011-2016), small companies were found to have engaged more in creative accounting more than big companies in 2012, 2015 and 2016. On the other hand, big companies were found to have manipulated their earnings more than small companies in 2012, 2013 and 2014. Nevertheless, on the average, the percentage of small companies that manipulated their earnings during the entire period 2011-2016 was found to be more than that of big companies, which was $28.4 \%$ as compared to $25.4 \%$ for big companies. However, the Mann-Whitney U Test analysis conducted showed that there was no statistically 
significant difference between the level of earnings manipulation amongst small and big companies. This finding contracts the school of thought that earnings manipulation and company size are statistically significantly negatively related (Alwan, 2009 as cited in Wuryani, 2012; Veronica \& Siddharta, 2005 as cited in Wuryani, 2012; Zhu \& Lu, 2013). The finding also contradicts the positive relationship view held by Li (as cited in Behrahani and Pajoohi, 2016), Sayari et al. (2013) and Wasila (as cited in Wuryani, 2012) in terms of statistical significance. The Spearman correlation analysis conducted between earning manipulation and share prices on the entire sampled companies indicated that there is statistically significant relationship between the two variables based on the Spearman correlation coefficient of -0.268 and p-value of 0.240 generated. Similarly, the Spearman correlation analysis performed on earnings manipulation and share prices separately on small and big companies showed that no statistically significant association exist between the two variables. These findings contract the assertion that share price and earnings manipulation is related negatively as propounded by Beneish (1999), Christianto and Budiharta (2014) and Nuryman (2013) or positively as supported by Lufti et al. (2016) and Zhu and Lu (2013) in terms of statistical significance. The finding is also an indication that other factors apart from earnings manipulation affect share price.

This quantitative research provides an insight into the level of earning manipulations in listed companies in Ghana. The evidence of incidence of earning manipulation uncovered through this research is an eye-opener and a wakeup call for regulators, auditors and investors to be more stringent in dealing with the listed companies on the Ghana Stock Exchange. The quantitative research also provides substantial knowledge on the use of the M-score model as well as circumstance in which is appropriate to use. The findings of this research demonstrate that either the various stakeholders responsible for ensuring that the companies listed on the GSE publish financial statements that are authentic and free of manipulation, have paid little attention to a possible earnings manipulation or whichever tools being used by them in detecting such unwholesome practices have not been effective since those companies found to be have manipulated their earnings in this research are yet to be detected and sanctioned. This is also a confirmation of Wuerges and Borba (2010)'s finding that there is a very high probability of not detecting fraud by U.S. Securities and Exchange Commission, estimating approximately $97.61 \%$.

\subsection{Recommendation}

\subsubsection{Practical Recommendation}

This quantitative research and others have revealed that publishing of impressive financial report may not be a true reflection of the firm's performance as evidenced in the case of Lehman Brothers (Sharp, 2010 as cited in Adu-Gyamfi, 2016). This is an indication that tools used by auditors, regulatory bodies and other stakeholders to verify the authenticity of financial information have done little in detecting earnings manipulation (Wuerges \& Borba, 2010). The reason is not farfetched. These stakeholders responsible for ensuring that those deceptive financial data are not published and relied on, either have little or no knowledge of existence of effective earnings manipulation detection tool such as M-scores or have no 
training in applications of such models even if they may be aware (Beneish, 1999). It is for this reason that organization of seminars and workshop aimed at training of stakeholders such as SEC, GSE, stockbrokers, fund managers, auditors, and analysts on M-score and its application is highly recommended. With the adequate knowledge, analysts will have the opportunity of verifying the authenticity of financial reports using M-score before analyzing them, auditors can apply M-score to compliment the use auditing procedure (Nwoye et al. (2012), fund managers will be better positioned to make good investment decisions for their clients, regulatory bodies such as SEC will be able to sanction culprits of earnings manipulations. In this case, incidence of earning manipulation will be minimized if not eradicated, investors' interest will be safeguard and the confidence in the capital market will be preserved.

\subsubsection{Recommendation for Further Research}

This research provides meaningful insight into detection of earnings manipulation in Ghana. The usefulness of Beneish M-score model is very evident in this research. Future researchers can analyze the possibility of earnings manipulation by listed companies on the Bourse Régionale des Valeurs Mobilières (BRVM) and Nigerian Stock Exchange in West Africa. Even though Nwoye, Okoye, and Osaka (2012) have undertaken a study using Beneish M-score on some public firms on the Nigerian Stock Exchange, the sample size was only five companies out of over 170 listed companies. An increase in the sample size will be more representative. A comparative analysis of the three exchanges using Beneish M-score model is also left to be explored in future research as an extension to this study. Finally, other researchers can explore the relationship between earnings manipulation and financial distress.

\section{References}

ACFE. (2016). Reports to the nations on occupational fraud and abuse: 2016 Global Fraud Study. [Online] Retrieved from https://s3-us-west-2.amazonaws.com/acfepublic/2016-report-to-the-nations.pdf

Acquah, B. (2016). Empirical analysis of macroeconomic variability on the Ghanaian stock market: A Vector Autoregression Approach. Macrothink Institute, 3(2), 49-88. https://doi.org/10.5296/ifb.v3i2.9821

Acquah-Sam, E. (2014). Effect of capital market development on economic growth in Ghana. European Scientific Journal, 10(7), 511-534. Retrieved from http://www.eujournal.org/index.php/esj/article/view/3000/2826

Acquah-Sam, E. (2016). Determinants of capital market development in Ghana. European Scientific Journal, 12(1), 251-270. https://doi.org/10.19044/esj.2016.v12n1p251

Adam, A. M., \& Tweneboah, G. (2009). Foreign Direct Investment (FDI) and stock market development: Ghana's evidence. International Research Journal of Finance and Economics, 26, 178-185. Retrieved from https://papers.ssrn.com/sol3/papers.cfm?abstract_id=1289843

Adkins. (n.d.). Financial statement manipulation-An ever-present problem for investors. Retrieved from 
http://www.investopedia.com/articles/fundamental-analysis/financial-statement-manipulation. asp

Adu-Gyamfi, M. (2016). The bankruptcy of Lehman Brothers: Causes, effects and lessons learnt. Journal of Insurance and Financial Management, 1(4), 131-148. Retrieved from https://journal-of-insurance-and-financial-management.com/index.php/JIFM/article/view/36

Adusei, M. (2014). Does stock market development promote economic growth in Ghana? International Journal of Economics and Finance, 6(6), 119-126. https://doi.org/10.5539/ijef.v6n6p119

Aghghaleh, S. F., Mohammed, Z. M., \& Rahmat, M. M. (2016). Detecting financial statement frauds in Malaysia: Comparing the abilities of Beneish and Dechow models. Asian Journal of Accounting and Governance, 7, 57-65. https://doi.org/10.17576/AJAG-2016-07-05

Ahmed, T., \& Naima, J. (2016). Detection and analysis of probable earnings manipulation by firms in a developing country. Asian Journal of Business and Accounting, 9(1), 59-81. Retrieved from http://umepublication.um.edu.my/filebank/published_article/9911/AJBA9(1)-Paper3.pdf

Amoa-Gyarteng, K. (2014). Analyzing a listed firm in Ghana for early warning signs of bankruptcy and financial statement fraud: An empirical investigation of AngloGold Ashanti. European Journal of Business and Management, 6(5), 10-17. Retrieved from http://iiste.org/Journals/index.php/EJBM/article/view/10908/11211

Angko, W. (2013). The determinants of stock market volatilities in Ghana. Research Journal of Finance and Accounting, 4(13), 146-165. Retrieved from http://iiste.org/Journals/index.php/RJFA/article/view/7795/7939

Anh, N. H., \& Linh, N. H. (2016). Using the M-score model in detecting earnings management: Evidence from non-financial Vietnamese listed companies. VNU Journal of Science: Economics and Business, 32(2), 14-23. Retrieved from https://js.vnu.edu.vn/EAB/article/view/1287/1251

Anyamele, O. D. (2013). Trends in stock market in Sub-Saharan Africa. International Journal of Research and Economics, 4(6), 62-78. Retrieved from http://ijeronline.com/documents/volumes/Vol4Iss6ND2013/ijer\%20v4i6\%20nd\%20(6a)\%20o kechuvukku.pdf

Aris, N. A., Othman, R., Arif, S. M. M., Malek, M. A. A., \& Omar, N. (2013). Fraud Detection: Benford's Law vs Beneish Model. Retrieved from http://www.academia.edu/25040350/Fraud_Detection_Benfords_Law_vs_Beneish_Model

Aryeetey, E., \& Kanbur, R. (Eds.). (2017). The economy of Ghana sixty years after independence. Oxford: Oxford University Press. https://doi.org/10.1093/acprof:oso/9780198753438.001.0001

Ayentimi, D. T., Mensah, A. E., \& Naa-Idar, F. (2013). Stock market efficiency of Ghana Stock Exchange: An objective analysis. International Journal of Management, Economics 
and Social Sciences, 2(2), 54-75. Retrieved from http://www.ijmess.com/volumes/volume-II-2013/issue-II-06-2013/full-1.pdf

Bank of Ghana. (2009). Bank of Ghana annual report 2009. Retrieved from https://www.bog.gov.gh/

Bank of Ghana. (2015). Bank of Ghana annual report 2015. Retrieved from https://www.bog.gov.gh/

Bank of Ghana. (2017). Bank of Ghana annual report 2017. Retrieved from https://www.bog.gov.gh/

Bank of Ghana. (2018, August 1). Government establishes new indigenous bank; Bank of Ghana revokes licenses of five banks and appoints receiver in respect of their assets and liabilities. [Press release]. Retrieved from http://bog.gov.gh/public-notices/3679-press-release-govt-establishes-new-indigenous-bank

Behrahani, H. F., \& Pajoohi, M. R. (2016). Examining the effect of firm size on conservatism and earnings manipulation relationships: Evidences from Tehran Stock Exchange. Journal of Novel Applied Sciences, 2, 776-783. Retrieved from www.jnasci.org

Beneish, M. (1997). Detecting GAAP violation: Implications for assessing earnings management among firms with extreme financial performance. Journal of Accounting and Public Policy, 16(3), 271-309. Retrieved from https://doi.org/10.1016/S0278-4254(97)00023-9

Beneish, M. D. (1999). The detection of earnings manipulation. Financial Analysts Journal, 55(5), 24-36. https://doi.org/10.2469/faj.v55.n5.2296

Beneish, M., Lee, C., \& Nichols, D. (2011). To catch a thief: can forensic accounting help predict stock returns? https://doi.org/10.2139/ssrn.1903593

Beneish, M. D., Lee, C. M. C., \& Nichols, D. C. (2013). Earnings manipulation and expected returns. Financial Analysts Journal, 69(2), 57-89. https://doi.org/10.2469/faj.v69.n2.1

Boachie, M. K., Mensah, I. O., Frimpong, A. O., \& Martin, R. (2016). Interest rate, liquidity and stock market performance in Ghana. International Journal of Accounting and Economics Studies, 4(1), 46-51. https://doi.org/10.14419/ijaes.v4i1.5990

Caprio, G., Arner, D. W., Beck, T., Calomiris, C. W., Neal, L., \& Véron, N. (Eds.). (2013). Handbook of key global financial markets, institutions, and infrastructure. London: Elsevier. Retrieved from https://books.google.tg

Carver, R. H., \& Nash, J. G. (2009). Doing data analysis with SPSS version 16. Belmont, CA: Brooks/Cole Cengage Learning. Retrieved from https://books.google.tg

Chadha, P. (2016). Fraud examination of Enron Corp. International Journal of Accounting Research, 1(7), 1-4. https://doi.org/10.4172/2472-114X.S1-007

Charoenwong, C. (2008). Earnings management to exceed thresholds: Evidence from 
Singapore and Thailand. https://doi.org/10.2139/ssrn.1104523

Chongsirithitisak, T. (2015). Detection of creative accounting in financial statements by model the case study of companies listed on the stock exchange of Thailand (pp. 199-204). The 2015 WEI International Academic Conference Proceedings. Retrieved from https://www.westeastinstitute.com/wp-content/uploads/2015/02/Thanathon-Chongsirithitisak. pdf

Christianto, W. (2014). The effect of earnings manipulation with using m-score on stock return: Empirical evidence in Indonesia listed companies on LQ45 at Indonesia Stock Exchange Period 2009-2011 (Dissertation). University of Atma Jaya Yogyakarta, Yogyakarta, Indonesia. Retrieved from http://e-journal.uajy.ac.id/6143/

Cohen, J., \& Cohen, P. (2013). Applied multiple regression / correlation for the behavioral sciences (3rd ed.). [e-book]. https://doi.org/10.4324/9780203774441

Cohen, P., West, S. G., \& Aiken, L. S. (2014). Applied multiple regression/correlation analysis for the behavioral sciences (2nd ed.). [e-book]. https://doi.org/10.4324/9781410606266

Corder, G. W., \& Forman, D. I. (2011). Nonparametric statistics for non-statisticians. Hoboken, New Jersey: John Wiley \& Sons. Retrieved from https://books.google.com

Creswell, J. W. (2014). Research Design: Qualitative, quantitative and mixed methods. London: Sage Publications Ltd. Retrieved from https://books.google.com.

de la Merced, M. J., \& Werdigier, J. (2010, March 12). The origins of Lehman's 'Repo 105'. The New York Times. Retrieved from https://dealbook.nytimes.com

Dichev, I., Graham, J., Harvey, C. R., \& Rajgopal, S. (2016). The Misrepresentation of Earnings. Financial Analysts Journal, 72(1), 22-35. https://doi.org/10.2469/faj.v72.n1.4

Eldenburg, L. G., Gunny, K. A., Hee, K. W., \& Soderstrom, N. (2011). Earnings Management Using Real Activities: Evidence from Nonprofit Hospitals. Accounting Review, 86(5), 1605-1630. https://doi.org/10.2308/accr-10095

Elliott, A. C., \& Woodward, W. A. (2014). IBM SPSS by example: A practical guide to statistical data analysis (2nd ed.). Thousand Oaks, California: SAGE Publications, Inc. Retrieved from https://books.google.com

Emmel, N. (2013). Sampling and choosing cases in qualitative research: A realist approach. London: Sage Publications Ltd. https://doi.org/10.4135/9781473913882

Filip, A., \& Raffournier, B. (2014). Financial crisis and earnings management: The European evidence. The International Journal of Accounting, 49(4), 455-478. https://doi.org/10.1016/j.intacc.2014.10.004

Ge, W., \& Kim, J. (2014). Boards, takeovers protection, real earnings management. Review of Quantitative Finance and Accountancy, 43(4), 651-682. https://doi.org/10.1007/s11156-013-0388-2 
Ghana Stock Exchange. (2014). Market report: December 2014 - (Full Year). [Online]. Retrieved from https://gse.com.gh/

Ghana Stock Exchange. (2015). Market report: December 2015 - (Full Year). [Online]. Retrieved from https://gse.com.gh/

Ghana Stock Exchange. (2016a). Market report. [Online]. Retrieved from https://gse.com.gh/

Ghana Stock Exchange. (2016b). The past, present and future of stock exchange operations in Ghana (Word file). [Online]. Retrieved from https://gse.com.gh/docs/2015/GSE_Anniversary_Handout.pdf

Ghana Stock Exchange. (2017). Market Report. [Online]. Retrieved from https://gse.com.gh/about/Structure-and-Function

Goel, S. (2014). The quality of reported numbers by the management: A case testing of earnings management of corporate India. Journal of Financial Crime, 21(3), 355-376, https://doi.org/10.1108/JFC-02-2013-0011

Gravetter, F. J., \& Wallnau, L. B. (2017). Statistics for the behavioral sciences (10th ed.). Boston, MA: Cengage Learning. Retrieved from https://books.google.com

Hare, J. O. (2013). Analyzing financial statements for non-specialists. [e-book]. Retrieved from https://books.google.com

Harrison, L., \& Callan, T. (2013). Key research concepts in politics \& relations. London: Sage Publications Ltd. https://doi.org/10.4135/9781526435897

Hirsch, J. A. (2012). The little book of stock market cycles. Hoboken, New Jersey: John Wiley $\&$ Sons. Retrieved from https://books.google.com

Höglund, H. (2012). Detecting earnings management with neural networks. Expert Systems with Applications, 39(10), 9564-9570. https://doi.org/10.1016/j.eswa.2012.02.096

Hollander, M., Wolfe, D. A., \& Chicken, E. (2013). Nonparametric statistical methods (3rd ed.). Hoboken, New Jersey: John Wiley \& Sons. Retrieved from https://books.google.com

IC Securities. (2011). Circular to all shareholders of Guinness Ghana Breweries Limited in respect of a renounceable rights issue of 46,666,667 ordinary shares of no par value at GHS2.50 per share in the ratio of 1 new shares for every 3.5287 existing shares held by a qualifying shareholder. Accra: IC Securities. Retrieved from htttp://www.annualreportsghana.com.

Jeffers, A. E. (2011). How Lehman Brothers used Repos 105 to manipulate their financial statements. Journal of Leadership, Accountability and Ethics, 8(5), 44-55. Retrieved from http://www.na-businesspress.com/JLAE/JeffersAE_Web8_5_.pdf

Jun, J. (2014, January 8). Using Beneish M Score to detect earnings manipulation. Retrieved from

http://www.valuewalk.com/2014/01/using-beneish-m-score-to-detect-earnings-manipulation 
Kanapickiene, R., \& Grundiene, Z. (2015). The model of fraud detection in financial statements by means of financial ratios. Procedia - Social and Behavioral Sciences, 213, 321-327. Retrieved from http://www.sciencedirect.com

Kighir, A., Omar, N., \& Mohammed, N. (2014). Earnings management detection modeling: A methodological review. World Journal of Social Sciences, 4(1), 18-32. Retrieved from http://www.wjsspapers.com/static/documents/March/2014/2.\%20Apedzan.pdf

Konrad Adenauer Foundation. (2006). Workshop report on public safety the role of the security agencies. Accra: Konrad Adenauer Foundation.

Kumar, V. (2017). Balance Sheet made easy. [e-book]. Retrieved from https://books.google.tg

Levy, P. S., \& Lemeshow, S. (2013). Sampling of populations: Methods and applications (4th ed.). Hoboken, New Jersey: John Wiley \& Sons. Retrieved from books.googgle.com

Loverland, J. L. (2014). Traditional lecture versus an activity approach for teaching statistics: A comparison of outcomes. Unpublished doctoral dissertation. Utah State University, Logan, Uta.

Retrieved

from

http://iase-web.org/documents/dissertations/1616.JenniferLLoverland.Dissertation.pdf

Lutfi, M., Nazwar, C., \& Muda, I. (2016). Effects of investment opportunity set, company size, and real activity manipulation of issuers in Indonesia Stock Exchange on stock price in Indonesia. IJER, 13(5), 2149-2161. Retrieved from http://www.serialsjournals.com/serialjournalmanager/pdf/1477633421.pdf

Mahama, M. (2015). Detecting corporate fraud and financial distress using the Altman and Beneish models-The case of Enron Corp. International Journal of Economics, Commerce and Management, $\quad 3(1), \quad 1-8 . \quad$ Retrieved from http://ijecm.co.uk/wp-content/uploads/2015/01/3159.pdf

Mamo, J., \& Aliaj, A. (2014). Accounting manipulation and its effects in the financial statements of Albanian entities. Interdisplinary Journal of Research and Development, 1(2), $55-60$.

Retrieved

from

http://www.uamd.edu.al/new/wp-content/uploads/2015/07/11.-J.Mamo_.pdf

Marinakis, P. (2011). An investigation of earnings management and earnings manipulation in the UK. Doctoral dissertation. University of Nottingham, Nottingham, United Kingdom

Matthews, T. D., \& Kostelis, K. T. (2011). Designing and conducting research in health and human performance. San Francisco, CA: John Wiley \& Sons, Inc. Retrieved from https://books.google.com

McLeavey, D. (2013, July 29). Detecting earnings manipulation and fraud: A light tutorial on Probit Analysis [Blog post]. Retrieved from https://blogs.cfainstitute.org/investor/2013/07/29/detetecting-earnings-manipulation-and-frau d-a-light-tutorial-on-probit-analysis/

Mensah, M., Awunyo-Vitor, D., \& Sey, E. W. (2012). Challenges and prospects of the Ghana 
Stock Exchange. Developing Country Studies, 2(10), 1-9. Retrieved from http://www.iiste.org/Journals/index.php/DCS/article/view/3180/3231

Namazi, M., \& Maharluie, M. S (2015). Detecting earnings management via statistical and neural network techniques. International Journal of Economics and Management Engineering, 9(7), 2520-2528. Retrieved from https://pdfs.semanticscholar.org/2711/e32fe509b0a3349c8bfa988e3e935da03a2f.pdf

Noor, N. F. M., Sanusia, Z. M., Heang, L. T., Iskandar, T. M., \& Isa, Y. M. (2015). Fraud motives and opportunities factors on earnings manipulations. Procedia Economics and Finance, 28, 126-135. https://doi.org/10.1016/S2212-5671(15)01091-6

Nuryaman. (2013). The influence of earnings management on stock return and the role of audit quality as a moderating variable. International Journal of Trade, Economics and Finance, 4(2), 73-78. https://doi.org/10.7763/IJTEF.2013.V4.263

Nwoye, U, J., Okoye, E. I., \& Oraka, A. O. (2012). Beneish model as effective complement to the application of SAS No. 99 in the conduct of audit in Nigeria. Management and Administrative Sciences Review, 2(6), 640-655. Retrieved from https://papers.ssrn.com/sol3/papers.cfm?abstract_id=2819436

O'Dwyer, L. M., \& Bernauer, J. A. (2014). Quantitative research for the qualitative researcher. Thousand Oaks, California: Sage Publications, Inc. https://doi.org/10.4135/9781506335674

Ofori-Abebrese, G., Amporfu, E., \& Adu, G. (2016). Does stock market development enhance private investment in Ghana? International Journal of Humanities and Social Science Research, 2, 68-78. Retrieved from http://www.lifescienceglobal.com/pms/index.php/ijhssr/article/view/3770/2204

Omar, N., Koya, R. K., Sanusi, Z. M., \& Shafie, N. A. (2014). Financial statement fraud: A case examination using Beneish Model and ratio analysis. International Journal of Trade, Economics and Finance, 5(2), 184-186. https://doi.org/10.7763/IJTEF.2014.V5.367

Ono, M. (2012, August 17). 8 high-profile financial scandals in 5 months. ABC News. Retrieved May 23, 2017, from http://abcnews.go.com/Business/high-profile-financial-scandals-months/story?id=17023140\#

Osamwonyi, I. O., \& Kasimu, A. (2013). Stock market and economic growth in Ghana, Kenya and Nigeria. International Journal of Financial Research, 4(2), 83-98. https://doi.org/10.5430/ijfr.v4n2p83

Owusu A., \& Amo, F. (2016). Effects of poor supervision on the sustainability of micro-financial institution in Ghana (A focus on Nkoranza Municipality in the Brong Ahafo Region). Advances in Sciences and Humanities, 2(3), 17-30. Retrieved from http://article.sciencepublishinggroup.com/html/10.11648.j.ash.20160203.11.html

Park, J. (2012). Developing and validating an instrument to measure college students' inferential reasoning in statistics. An Argument-Based Approach to Validation, 1-304. 
Retrieved from http://iase-web.org/documents/dissertations/12.Park.Dissertation.pdf

Pattarkine, U. (2014). Earnings manipulation and predicting stock returns. Pennsylvania: University of State University.

Rainbolt, G. W., \& Dwyer, S. L. (2012). Critical thinking: The art of argument. Boston. MA: Wadsworth Cengage Learning. Retrieved from https://books.google.com.

Repousis, S. (2016). Using Beneish model to detect corporate financial statement fraud in Greece. Journal of Financial Crime, 23(4), 1063-1073. https://doi.org/10.1108/JFC-11-2014-0055

Rovai, A. P., Baker, J. D., \& Poton, M. K. (2014). Research design and statistics: A practioner's guide to research methods and IBM SPSS analysis. Chesapeake, VA: Watertree Press LLC. Retrieved from https://books.google.com.

Roy, T. K., Acharya, R., \& Roy, A. K. (2016). Statistical survey design and evaluating impact. Delhi: Cambridge University Press. https://doi.org/10.1017/CBO9781316550892

Roychowdhury, S. (2006). Earnings management through real activities manipulation. Journal of Accounting and Economics, 42(3), 335-370. https://doi.org/10.1016/j.jacceco.2006.01.002

Roze, G. N. \& Roze, G. D. (2016). Tensile trading: The 10 essential stages of stock market Mastery. Hoboken, New York: John Wiley \& Sons, Inc. https://doi.org/10.1002/9781119227755

Sayari, S., Mraihi, F., Finet, A., \& Omri, A. (2013). The impact of earnings management on stock returns: The case of Tunisia Firms. Global Journal of Management and Business Research, 13(10), 50-65. Retrieved from https://globaljournals.org/GJMBR_Volume13/5-The-Impact-of-Earnings-Management.pdf

Securities and Exchange Commission. (2015). 2015 Annual Report. Retrieved from https://sec.gov.gh/wp-content/uploads/Annual-Reports/2014-Annual-Report.pdf

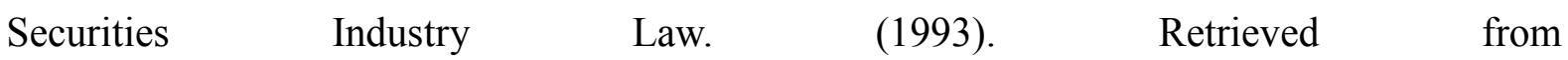
http://investinkumasi.com/wp-content/uploads/2013/09/Securities-Industry-Law-PNDCL-333 .pdf

Selinger, H. W., \& Shohamy, E. (2013). Second language research methods. Oxford: Oxford University Press. Retrieved from https://books.google.com

Shim, S. K. (2016). Accounting and finance for the nonfinancial executive: An integrated resources management guide for the 21st century. London: St. Lucie Press. Retrieved from https://books.google.com

Sidorova, A., Evangelopoulos, N., Torres, R., \& Johnson, V (2013). A survey of core research in information systems. New York: Springer. https://doi.org/10.1007/978-1-4614-7158-5

Sinha, G. (2012). Financial statements analysis (2nd ed.). [e-book]. Retrieved from 
https://books.google.tg

Sobrepena, Y. T. (n.d.). The research instruments [PowerPoint slides]. Retrieved from https://www.slideshare.net/argellee/the-research-instruments.

Speight, J. G. (2015). Handbook of petroleum product analysis (2nd ed.). Hoboken, New Jersey: John Wiley \& Sons. Retrieved from https://books.google.com

Stokes, P., \& Wall, T. (2014). Research Methods. London: Palgrave. https://doi.org/10.1007/978-1-349-92672-5

Tarjo, \& Herawati, N. (2015). Application of Beneish M-Score and Data Mining to detect Financial Fraud. Procedia Social and Behavioral Sciences, 211, 924-930. https://doi.org/10.1016/j.sbspro.2015.11.122

Upneja, A., Dalbor, M. C., Lee, S., \& Mao, Z. (2008). Impact of earnings manipulation on valuation of publicly traded restaurant firms in the United States. Journal of Foodservice Business Research, 124(2), 124-137. https://doi.org/10.1080/15378020801995531

Verma, J. P. (2013). Data analysis in management with SPSS software. New Delhi: Springer. https://doi.org/10.1007/978-81-322-0786-3

Wang, Y. (2014). Human population genetic research in developing countries: The issue of group protection. London: Routledge. https://doi.org/10.4324/9780203506820

Wayman, R. (2017). Top 8 ways companies cook the books. Retrieved from http://www.investopedia.com/articles/analyst/071502.asp

Weaver, K. F., Morales, V. C., Dunn, G. K., \& Weaver, P. F. (2018). An introduction to statistical analysis in research: With applications in biological and life sciences. Hoboken, New Jersey: John Wiley \& Sons, Inc.

Wuerges, A. F. E., \& Borba, J. A. (2010). Accounting fraud detection: Is it possible to quantify undiscovered cases? Unpublished manuscript. https://doi.org/10.2139/ssrn.1718652

Wuryani, E. (2012). Company size in response to earning management and company performance. Journal of Economics, Business, and Accountancy Ventura, 15(3), 491-506. https://doi.org/10.14414/jebav.v15i3.117

Xu, R. Z., \& Taylor, G. K. (2017). Effect of earnings management on firms' stock repurchases behavior. Journal of Finance and Accountancy, 22, 1-15. Retrieved from http://aabri.com/manuscripts/162539.pdf.

Yin, R. K. (2013). Case study research: Designs and methods (5th ed.). Washington, DC: Sage Publications Ltd. Retrieved from https: books.google.com

Zhu, X., \& Lu, S. (2013). Earnings management through real activities manipulation before mergers and acquisitions. Journal of Finance and Accountancy, 13, 1-6. Retrieved from http://www.aabri.com/jfa.html

Ziorklui, S. Q. (2001). The Development of Capital Markets and Growth in Sub-Saharan 
Africa: The Case of Ghana $\quad$ Retrieved from http://www.tandf.co.uk/journals/authors/style/reference/tf_APA.pdf

Zumbo, B. D., \& Chan, E. K. H. (Eds.). (2014). Validity and validation in social, behavioral, and health sciences. Cham: Springer. https://doi.org/10.1007/978-3-319-07794-9

\section{Copyright Disclaimer}

Copyright for this article is retained by the author(s), with first publication rights granted to the journal.

This is an open-access article distributed under the terms and conditions of the Creative Commons Attribution license (http://creativecommons.org/licenses/by/4.0/). 